\title{
Extensive spatiotemporal analyses of surface ozone and related meteorological variables in South Korea for the period 1999-2010
}

\author{
J. Seo ${ }^{1,3}$, D. Youn ${ }^{2}$, J. Y. Kim ${ }^{1}$, and H. Lee ${ }^{4}$ \\ ${ }^{1}$ Green City Technology Institute, Korea Institute of Science and Technology, Seoul, South Korea \\ ${ }^{2}$ Department of Earth Science Education, Chungbuk National University, Cheongju, South Korea \\ ${ }^{3}$ School of Earth and Environmental Sciences, Seoul National University, Seoul, South Korea \\ ${ }^{4}$ Jet Propulsion Laboratory, California Institute of Technology, Pasadena, CA, USA \\ Correspondence to: D. Youn (dyoun@chungbuk.ac.kr)
}

Received: 22 November 2013 - Published in Atmos. Chem. Phys. Discuss.: 15 January 2014

Revised: 25 April 2014 - Accepted: 14 May 2014 - Published: 26 June 2014

\begin{abstract}
Spatiotemporal characteristics of surface ozone $\left(\mathrm{O}_{3}\right)$ variations over South Korea are investigated with consideration of meteorological factors and timescales based on the Kolmogorov-Zurbenko filter (KZ filter), using measurement data at 124 air quality monitoring sites and 72 weather stations for the $12 \mathrm{yr}$ period of 1999-2010. In general, $\mathrm{O}_{3}$ levels at coastal cities are high due to dynamic effects of the sea breeze while those at the inland and Seoul Metropolitan Area (SMA) cities are low due to the $\mathrm{NO}_{\mathrm{x}}$ titration by local precursor emissions. We examine the meteorological influences on $\mathrm{O}_{3}$ using a combined analysis of the $\mathrm{KZ}$ filter and linear regressions between $\mathrm{O}_{3}$ and meteorological variables. We decomposed $\mathrm{O}_{3}$ time series at each site into short-term, seasonal, and long-term components by the KZ filter and regressed on meteorological variables. Impact of temperature on the $\mathrm{O}_{3}$ levels is significantly high in the highly populated SMA and inland region, but low in the coastal region. In particular, the probability of high $\mathrm{O}_{3}$ occurrence doubles with $4{ }^{\circ} \mathrm{C}$ of temperature increase in the SMA during high $\mathrm{O}_{3}$ months (May-October). This implies that those regions will experience frequent high $\mathrm{O}_{3}$ events in a future warming climate. In terms of short-term variation, the distribution of high $\mathrm{O}_{3}$ probability classified by wind direction shows the effect of both local precursor emissions and long-range transport from China. In terms of long-term variation, the $\mathrm{O}_{3}$ concentrations have increased by $+0.26 \mathrm{ppbv} \mathrm{yr}^{-1}$ (parts per billion by volume) on nationwide average, but their trends show large spatial variability. Singular value decomposition analyses further reveal that the long-term temporal evolution of $\mathrm{O}_{3}$ is similar to that of nitrogen dioxide, although the spa-
\end{abstract}

tial distribution of their trends is different. This study will be helpful as a reference for diagnostics and evaluation of regional- and local-scale $\mathrm{O}_{3}$ and climate simulations, and as a guide to appropriate $\mathrm{O}_{3}$ control policy in South Korea.

\section{Introduction}

Surface ozone $\left(\mathrm{O}_{3}\right)$ is a well-known secondary air pollutant, which affects air quality, human health, and vegetation. High $\mathrm{O}_{3}$ concentrations have detrimental effects on respiration, lung function, and airway reactivity in human health (Bernard et al., 2001; Bell et al., 2007). In terms of mortality, Levy et al. (2005) have previously assessed that a $10 \mathrm{ppbv}$ (parts per billion by volume) increase in $1 \mathrm{~h}$ maximum $\mathrm{O}_{3}$ could increase daily mortality by $0.41 \%$. High $\mathrm{O}_{3}$ concentrations could also reduce agricultural production. For example, Wang and Mauzerall (2004) reported that the East Asian countries of China, Japan, and South Korea lost 1-9\% of their yields of wheat, rice, and corn, and $23-27 \%$ of their yields of soybeans due to $\mathrm{O}_{3}$ in 1990. In addition, $\mathrm{O}_{3}$ is one of the greenhouse gases for which radiative forcing is estimated as the third largest contribution among the various constituents in the troposphere (IPCC, 2007). Therefore, the spatially inhomogeneous distribution of $\mathrm{O}_{3}$ due to its short chemical lifetime of a week to a month could induce strong regional-scale climate responses (Mickley et al., 2004).

In the Northern Hemisphere midlatitudes where population, industry, and transportation are concentrated, the background $\mathrm{O}_{3}$ levels increased during the late-20th century due 
to increases in anthropogenic precursors particularly nitrogen oxides $\left(\mathrm{NO}_{\mathrm{x}}\right)$, but its trends show regional and temporal differences (Oltmans et al., 1998; Guicherit and Roemer, 2000; Vingarzan, 2004). Although the increasing trends of $\mathrm{O}_{3}$ in Europe, the North Atlantic, North America, and Japan have flattened over the past decade (Oltmans et al., 2006, 2013), there have still been concerns about elevated $\mathrm{O}_{3}$ concentrations in China owing to rapid economic growth and industrialization (Ding et al., 2008; Tang et al., 2009; Wang et al., 2009, 2012). Such recent increases of $\mathrm{O}_{3}$ in China can affect the regional background $\mathrm{O}_{3}$ levels in East Asia by transboundary transport of $\mathrm{O}_{3}$ and its precursors. For example, previous modeling studies have shown that the transport of $\mathrm{O}_{3}$ from China by continental outflow is one of the major contributions of $\mathrm{O}_{3}$ in Japan and South Korea (Tanimoto et al., 2005; Nagashima et al., 2010). Intercontinental transport of $\mathrm{O}_{3}$ and its precursors originated in East Asia affects $\mathrm{O}_{3}$ concentrations and air quality in remote areas even on a global scale (Akimoto, 2003). Experiments using a global climate-chemistry model with future emission scenarios by Lei et al. (2013) suggest that the increase in East Asian emissions will still be an important issue for the $\mathrm{O}_{3}$ air quality in both East Asia and the United States.

Recently, several studies have focused on the relationship between $\mathrm{O}_{3}$ levels and temperature, and suggested potential influences of the global warming and climate change on the high levels of $\mathrm{O}_{3}$ (Jacob and Winner, 2009; Rasmussen et al., 2012, and references therein). Lin et al. (2001) calculated probability of daily maximum $8 \mathrm{~h}$ average $\mathrm{O}_{3}$ exceeding $85 \mathrm{ppbv}$ for a given range of daily maximum temperatures and reported that a $3{ }^{\circ} \mathrm{C}$ increase of the daily maximum temperature doubles risk of $\mathrm{O}_{3}$ exceedances in the northeastern United States. In addition, Ordóñez et al. (2005) showed that high temperature extremes probably led to the high occurrence of severe $\mathrm{O}_{3}$ episodes during the summer 2003 heat wave over Europe. These results imply the potentially large sensitivity of $\mathrm{O}_{3}$ concentration and related air quality to the temperature increases (Jacob and Winner, 2009). In the model experiments by Lin et al. (2008), both averaged $\mathrm{O}_{3}$ concentrations and frequencies of high $\mathrm{O}_{3}$ episodes were predicted to increase in future over the United States and East Asia. Recent global climate-chemistry model experiments by Lei and Wang (2014) also implied the future $\mathrm{O}_{3}$ increases in industrial regions due to more $\mathrm{O}_{3}$ production by photochemical reactions and less $\mathrm{O}_{3}$ removal by nocturnal odd nitrogen $\left(\mathrm{NO}_{\mathrm{y}}\right)$ chemistry in warmer conditions.

In South Korea, one of the most densely populated countries in the world, both $\mathrm{O}_{3}$ concentrations and high $\mathrm{O}_{3}$ episodes have increased in recent decades despite efforts to regulate emissions of $\mathrm{O}_{3}$ precursors (KMOE, 2012). Although the increase of $\mathrm{O}_{3}$ levels in South Korea over the last 3 decades is mainly regarded as the results of rapid industrialization, economic expansion, and urbanization, there are other factors to be considered to explain the long-term increase in $\mathrm{O}_{3}$ concentrations. For example, since the Ko- rean Peninsula is located on the eastern boundary of East Asia, downward transport of $\mathrm{O}_{3}$ by the continental outflow considerably affects the high $\mathrm{O}_{3}$ levels in South Korea $(\mathrm{Oh}$ et al., 2010). In addition, a recent warming trend related to global climate change could also be an important factor to increase $\mathrm{O}_{3}$ concentrations in South Korea. Climate change is expected to increase both frequency and intensity of temperature extremes over the Korean Peninsula (Boo et al., 2006). Therefore, comprehensive understanding of the various factors affecting $\mathrm{O}_{3}$ concentrations, such as local precursor emissions, transport of $\mathrm{O}_{3}$ and its precursors from local and remote sources, and changes in meteorological fields related to climate change is required to guide environmental policies.

The present study aims to examine the spatiotemporal characteristics of the measured $\mathrm{O}_{3}$ variations in South Korea with consideration of three timescales and various meteorological factors, using ground-measured data from 124 air quality monitoring sites and 72 weather stations for the $12 \mathrm{yr}$ period of 1999-2010. We decomposed $\mathrm{O}_{3}$ time series at each measurement site into different timescales of shortterm, seasonal, and long-term components by application of the Kolmogorov-Zurbenko filter (KZ filter) that has been used in previous studies (e.g., Gardner and Dorling, 2000; Ibarra-Berastegi et al., 2001; Thompson et al., 2001; Lu and Chang, 2005; Wise and Comrie, 2005; Tsakiri and Zurbenko, 2011; Shin et al., 2012). To investigate the meteorological impact on the $\mathrm{O}_{3}$ levels, we applied the combined analysis of the KZ filter and linear regression model with the meteorological variables. In the short-term timescale, the possible effects of transport from the local and remote sources on the high $\mathrm{O}_{3}$ episodes were explored by using the wind data. In the long-term timescale, the singular value decomposition (SVD) with nitrogen dioxide $\left(\mathrm{NO}_{2}\right)$ measurements was additionally applied to examine the effects of varying local emissions on the long-term $\mathrm{O}_{3}$ trend.

The remainder of this paper is structured as follows. In the next section, we describe the observational data and analysis techniques used in this study. In Sect. 3, we investigate the spatiotemporal characteristics of the decomposed $\mathrm{O}_{3}$ time series and its relationship with meteorological variables over South Korea. Finally, the key findings are summarized in Sect. 4.

\section{Data and methodologies}

\subsection{Data}

The National Institute of Environmental Research (NIER) of South Korea provides hourly data of $\mathrm{O}_{3}$ and $\mathrm{NO}_{2}$ mixing ratios in the ppbv unit, which have been measured by ultraviolet absorption and chemiluminescence, respectively. We here select 124 urban air quality monitoring sites over South Korea, based on data availability for the period 1999-2010, and 
analyze hourly time series of $\mathrm{O}_{3}$ and $\mathrm{NO}_{2}$ from each site. It is noted that our current analyses exclude other data from roadside measurement sites where data can be directly affected by the vehicle exhaust emissions and suburban and background sites located around South Korea. Hourly meteorological data at 72 weather stations of the Korea Meteorological Administration (KMA) for the same period are also used to examine the effects of meteorological factors on the $\mathrm{O}_{3}$ variations. The meteorological variables used in this study include common factors related to the $\mathrm{O}_{3}$ variations such as temperature $\left({ }^{\circ} \mathrm{C}\right)$, surface insolation $\left(\mathrm{W} \mathrm{m}^{-2}\right)$, relative humidity (\%), and wind speed $\left(\mathrm{m} \mathrm{s}^{-1}\right)$ (e.g., Ordóñez et al., 2005; Camalier et al., 2007; Jacob and Winner, 2009). Dewpoint temperature $\left({ }^{\circ} \mathrm{C}\right)$ and sea-level pressure $(\mathrm{hPa})$ are additionally applied for multiple linear regression models as other previous studies have done (e.g., Thompson et al., 2001; Shin et al., 2012). Finally, wind direction (16 cardinal directions) is used to reveal its relationship with short-term changes in $\mathrm{O}_{3}$. Using the hourly data, we first calculated daily averages for $\mathrm{O}_{3}\left(\mathrm{O}_{3}\right.$ avg $), \mathrm{NO}_{2}\left(\mathrm{NO}_{2 \text { avg }}\right)$, temperature $(T)$, surface insolation (SI), dew-point temperature (TD), sea-level pressure (PS), wind speed (WS), wind direction (WD), and relative humidity $(\mathrm{RH})$. We also obtained daily minimum $\mathrm{O}_{3}$ $\left(\mathrm{O}_{3 \text { min }}\right)$, daily maximum $8 \mathrm{~h}$ average $\mathrm{O}_{3}\left(\mathrm{O}_{38 \mathrm{~h}}\right)$, and daily maximum temperature $\left(T_{\max }\right)$ from the hourly data set.

To investigate the relationship between $\mathrm{O}_{3}$ and meteorological variables, it is desirable to use data observed at the same stations. However, not all air quality monitoring sites and weather stations are closely located in South Korea. Therefore, we assume that an air quality monitoring site can observe the same meteorological variables as those at a weather station if the distance between the two places is less than $10 \mathrm{~km}$. Under this assumption, only $\mathrm{O}_{3}$ data from 72 air quality monitoring sites and meteorological data from 25 weather stations are available to analyze the meteorological effects on the $\mathrm{O}_{3}$ variation over South Korea. The insolation was measured only at 17 weather stations for the analysis period. Figure 1 shows geographical locations of the ground measurements used in the present study, together with colored topography based on the US Geological Survey (USGS) digital elevation model (DEM).

\subsection{Decomposition of $\mathrm{O}_{3}$ time series by $\mathrm{KZ}$ filter}

The KZ filter is a decomposition method that can be used to separate time series into short-term, seasonal, and long-term components (Rao and Zurbenko, 1994). We applied the KZ filter to the $\mathrm{O}_{3}$ time series by taking the moving average of window length $m$ with iterating $p$ times, which is denoted by $\mathrm{KZ}_{m, p}$. The KZ filter is basically a low-pass filter for removing high-frequency components from the original time series. Following Eskridge et al. (1997), the KZ filter removes the signal smaller than the period $N$, which is called as the ef- fective filter width. $N$ is defined as follows:

$m \times p^{1 / 2} \leq N$.

The KZ-filter method has the same level of accuracy as the wavelet transform method although it is a much easier way to decompose the original time series (Eskridge et al., 1997). In addition, time series with missing observations can be applicable to the KZ filter owing to the iterative moving average process.

For the clear separation of the components, we applied the KZ filter to the daily log-transformed $\mathrm{O}_{3}$ as in Rao and Zurbenko (1994) and Eskridge et al. (1997), instead of the raw $\mathrm{O}_{3}$ concentrations. While the short-term component separated by the $\mathrm{KZ}$ filter using raw $\mathrm{O}_{3}$ data still shows clear seasonality, use of $\ln \left(\mathrm{O}_{3}\right)$ makes the short-term component stationary and nearly independent of the seasonal influence by stabilizing variance (Rao and Zurbenko, 1994; Rao et al., 1997). Note that a temporal linear trend of log-transformed data is provided as percent per year $\left(\% \mathrm{yr}^{-1}\right)$ because the differential of the natural logarithm is equivalent to the percentage change.

The natural logarithm of the $\mathrm{O}_{3}$ time series at each site denoted as $\left[\mathrm{O}_{3}\right](t)$ is thus decomposed by the $\mathrm{KZ}$ filter as follows:

$\left[\mathrm{O}_{3}\right](t)=\left[\mathrm{O}_{3 \mathrm{ST}}\right](t)+\left[\mathrm{O}_{3 \mathrm{SEASON}}\right](t)+\left[\mathrm{O}_{3 \mathrm{LT}}\right](t)$.

$\left[\mathrm{O}_{3 \mathrm{ST}}\right]$ is a short-term component attributable to day-to-day variation of synoptic-scale weather and short-term fluctuation in precursor emissions. $\left[\mathrm{O}_{3 \mathrm{SEASON}}\right]$ represents a seasonal component related to the seasonal changes in solar radiation and vertical transport of $\mathrm{O}_{3}$ from the stratosphere whose timescale is from several weeks to months. $\left[\mathrm{O}_{3 \mathrm{LT}}\right]$ denotes a long-term component explained by changes in precursor emission, transport, climate, policy, and economy over the entire period (Rao et al., 1997; Milanchus et al., 1998; Gardner and Dorling, 2000; Thompson et al., 2001; Wise and Comrie, 2005). Tsakiri and Zurbenko (2011) showed that $\left[\mathrm{O}_{3 \mathrm{ST}}\right]$ and $\left[\mathrm{O}_{3 \mathrm{LT}}\right]$ are independent of each other. Also, statistical characteristics of $\left[\mathrm{O}_{3 \mathrm{ST}}\right]$ are very close to those of white noise (Flaum et al., 1996) and therefore $\left[\mathrm{O}_{3 \mathrm{ST}}\right]$ is nearly detrended.

In this study, we used the KZ filter with the window length of 29 days and 3 iterations $\left(\mathrm{KZ}_{29,3}\right)$ following previous studies (e.g., Rao and Zurbenko, 1994) and decomposed daily $\ln \left(\mathrm{O}_{38 \mathrm{~h}}\right)$ time series at the 124 monitoring sites. $\mathrm{KZ}_{29,3}$ removes the $\left[\mathrm{O}_{3 \mathrm{ST}}\right]$ with period shorter than about 50 days, following Eq. (1). We defined the filtered time series as a baseline $\left(\left[\mathrm{O}_{3 \mathrm{BL}}\right]\right)$ as in Eq. (3).

$\left[\mathrm{O}_{3}\right](t)=\left[\mathrm{O}_{3 \mathrm{BL}}\right](t)+\left[\mathrm{O}_{3 \mathrm{ST}}\right](t)$

Equation (3) accounts for the multiplicative effects of shortterm fluctuations on the $\left[\mathrm{O}_{3 \mathrm{BL}}\right]$ due to the log transformation (Thompson et al., 2001). In other words, the exponential of 
$\left[\mathrm{O}_{3 \mathrm{ST}}\right]$ is a ratio of the raw $\mathrm{O}_{3}$ concentrations to the exponential of $\left[\mathrm{O}_{3} \mathrm{BL}\right]$, which is the baseline $\mathrm{O}_{3}$ concentration in ppbv. Therefore, if $\exp \left[\mathrm{O}_{3 \mathrm{ST}}\right]$ is larger than 1 , the raw $\mathrm{O}_{3}$ concentration will be larger than the baseline $\mathrm{O}_{3}$ concentration.

$\left[\mathrm{O}_{3 \mathrm{BL}}\right]$ is expressed as the sum of $\left[\mathrm{O}_{3 \mathrm{SEASON}}\right]$ and $\left[\mathrm{O}_{3 \mathrm{LT}}\right]$, as in Eq. (4) (Milanchus et al., 1998).

$\left[\mathrm{O}_{3 \mathrm{BL}}\right](t)=\left[\mathrm{O}_{3 \text { SEASON }}\right](t)+\left[\mathrm{O}_{3 \mathrm{LT}}\right](t)$

Since $\left[\mathrm{O}_{3 \mathrm{BL}}\right]$ is closely associated with meteorological fields, we built a multiple regression model with available meteorological variables as in Eq. (5), following previous studies (e.g., Rao and Zurbenko, 1994; Rao et al., 1995; Ibarra-Berastegi et al., 2001). Short-term variability of meteorological variables was also filtered out by $\mathrm{KZ}_{29,3}$.

$$
\begin{aligned}
{\left[\mathrm{O}_{3 \mathrm{BL}}\right](t)=} & a_{0}+\sum_{i} a_{i} \operatorname{MET}_{\mathrm{BL}}(t)_{i}+\varepsilon(t) \\
\operatorname{MET}_{\mathrm{BL}}(t)= & {\left[T_{\max \mathrm{BL}}(t), \operatorname{SI}_{\mathrm{BL}}(t), \operatorname{TD}_{\mathrm{BL}}(t),\right.} \\
& \left.\operatorname{PS}_{\mathrm{BL}}(t), \operatorname{WS}_{\mathrm{BL}}(t), \operatorname{RH}_{\mathrm{BL}}(t)\right]
\end{aligned}
$$

In the multiple linear regression model, $\left[\mathrm{O}_{3 \mathrm{BL}}\right]$ is a response variable and the baselines of meteorological variables $\left(\operatorname{MET}_{\mathrm{BL}}(t)_{i}\right)$ are predictors. Also, $a_{0}, a_{i}$, and $\varepsilon(t)$ denote the constant, regression coefficient of variable $i$, and residual of the multiple regression model, respectively.

The residual term $\varepsilon(t)$ contains not only the long-term variability of $\mathrm{O}_{3}$ related to long-term changes in local precursor emissions but also seasonal variability of $\mathrm{O}_{3}$ attributable to unconsidered meteorological factors in the multiple linear regression model. Thus, we applied the KZ filter with the window length of 365 days and 3 iterations $\left(\mathrm{KZ}_{365,3}\right)$ to $\varepsilon(t)$ to extract the meteorologically adjusted $\left[\mathrm{O}_{3 \mathrm{LT}}\right]$ of which the period is larger than about $1.7 \mathrm{yr}$ as follows:

$\varepsilon(t)=\mathrm{KZ}_{365,3}[\varepsilon(t)]+\delta(t)=\left[\mathrm{O}_{3 \mathrm{LT}}\right](t)+\delta(t)$.

In Eq. (6), $\delta(t)$ denotes the seasonal variability of $\mathrm{O}_{3}$ related to the meteorological variables unconsidered in the multiple linear regression model and/or noise.

Finally, $\left[\mathrm{O}_{3}\right.$ SEASON $]$ is obtained by sum of the combined meteorological variables regressed on $\left[\mathrm{O}_{3 \mathrm{BL}}\right]\left(a_{0}+\sum_{i} a_{i}\right.$ $\left.\operatorname{MET}_{\mathrm{BL}}(t)_{i}\right)$ and $\delta(t)$ as in Eq. (7).

$\left[\mathrm{O}_{3 \text { SEASON }}\right](t)=a_{0}+\sum_{i} a_{i} \operatorname{MET}_{\mathrm{BL}}(t)_{i}+\delta(t)$

Figure 2 shows a schematic representation of Eq. (2) using daily $\mathrm{O}_{38 \mathrm{~h}}$ time series at the City Hall of Seoul for the period of 1999-2010. [O 3 SEASON] in Fig. 2c clearly shows the typical seasonal cycle of $\mathrm{O}_{3}$ in South Korea with high concentrations in spring, slight decrease in July and August, and increase in autumn (Ghim and Chang, 2000). The spring maximum of $\mathrm{O}_{3}$ concentration in the Northern Hemisphere is generally attributed to episodic stratospheric intrusion (Levy et al., 1985; Logan, 1985), photochemical reactions of accumulated $\mathrm{NO}_{\mathrm{x}}$ and hydrocarbons during the winter (Dibb et al., 2003), accumulation of $\mathrm{O}_{3}$ due to the longer photochemical lifetime ( 200 days) during the winter (Liu et al., 1987), and transport of $\mathrm{O}_{3}$ and its precursors by the continental outflow (Carmichael et al., 1998; Jacob et al., 1999; Jaffe et al., 2003). However, frequent precipitation during the East Asian summer monsoon influences the decrease of $\mathrm{O}_{3}$ concentrations in July and August (Ghim and Chang, 2000). [O $\left.\mathrm{O}_{3 \mathrm{LT}}\right]$ in Fig. $2 d$ shows that the $\mathrm{O}_{3}$ concentrations at the monitoring site have increased in the past decade, irrespective of any change in meteorological conditions. It should be noted that $\left[\mathrm{O}_{3 \mathrm{LT}}\right]$ explains only $1.7 \%$ of the total variance of $\left[\mathrm{O}_{3}\right]$ at this site as can be seen from its small ranges in Fig. 2d, while relative contributions of $\left[\mathrm{O}_{3 \mathrm{ST}}\right]$ and $\left[\mathrm{O}_{3}\right.$ SEASON $]$ are 58.3 and $32.7 \%$, respectively. Therefore, the long-term changes in $\mathrm{O}_{3}$ related to changes in local emission are only a small fraction of the $\mathrm{O}_{3}$ variations. The relative contributions of each component are further examined in Sect. 3.4.

\subsection{Spatial interpolation by AIDW method}

Inverse-distance weighting (IDW) is a deterministic spatial interpolation technique for spatial mapping of variables distributed at irregular points. In this study, we adopted the enhanced version of the IDW, the adaptive inverse-distance weighting (AIDW) technique (Lu and Wong, 2008). While the traditional IDW uses a fixed distance-decay parameter without considering the distribution of data within it, the AIDW uses adjusted distance-decay parameters according to density of local sampling points. Therefore, the AIDW provides flexibility to accommodate variability in the distancedecay relationship over the domain and thus better spatial mapping of variables distributed at irregular observational points (Lu and Wong, 2008).

In the mapping of $\mathrm{O}_{3}$ with spatial interpolation, there are ubiquitous problems such as spatial-scale violations, improper evaluations, inaccuracy, and inappropriate use of $\mathrm{O}_{3}$ maps in certain analyses (Diem, 2003). The spatial mapping in the present study also has problems with the spatial resolution of the observations, which is not high enough to consider small-scale chemical processes and the geographical complexity of the Korean Peninsula (see Fig. 1). Most of the air quality monitoring sites are concentrated on the cities, and typical intercity distances are $30-100 \mathrm{~km}$ in South Korea while spatial representativeness of $\mathrm{O}_{3}$ concentrations is possibly as small as around 3-4 (Tilmes and Zimmermann, 1998) or $5 \mathrm{~km}$ (Diem, 2003). In addition, mapping with a few monitoring sites combined with complex mountainous terrain can also distort the actual distribution of data, especially in the northeastern part of South Korea. Despite such limits, the spatial mapping in this study is still useful because we aim not to derive an exact value at a specific point where the observation does not exist, but to provide the better quantitative understanding of $\mathrm{O}_{3}$ and related factors in South 

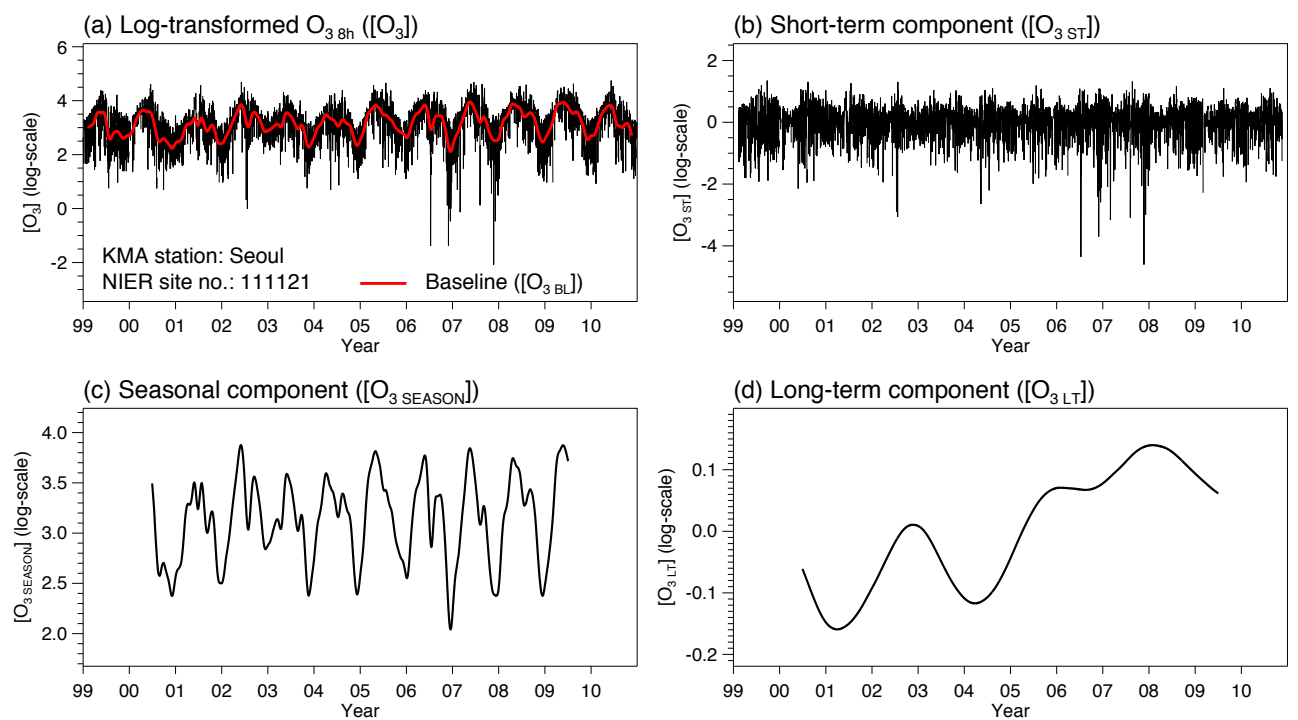

Figure 1. Time series of daily maximum $8 \mathrm{~h}$ average ozone $\left(\mathrm{O}_{38} \mathrm{~h}\right)$ at the City Hall of Seoul and its separated components such as (a) logtransformed $\mathrm{O}_{38 \mathrm{~h}}$ time series $\left(\left[\mathrm{O}_{3}\right]\right)$ and its baseline $\left(\left[\mathrm{O}_{3 \mathrm{BL}}\right]\right)$, (b) short-term component $\left(\left[\mathrm{O}_{3 \mathrm{ST}}\right]\right)$, (c) seasonal component $\left(\left[\mathrm{O}_{3 \mathrm{SEASON}}\right]\right)$, and (d) long-term component $\left(\left[\mathrm{O}_{3 \mathrm{LT}}\right]\right)$ by applying the $\mathrm{KZ}$ filter. It is noted that the longer window length causes the larger truncation of the result (Wise and Comrie, 2005) since the KZ filter is an iterative moving average process. The baseline (red solid line) is superimposed in (a).

Korea, especially focused on the metropolitan and urban areas.

\section{Results}

\subsection{Spatial characteristics of $\mathrm{O}_{3}$ and its trend in South Korea}

Climatological daily average $\mathrm{O}_{3}\left(\mathrm{O}_{3}\right.$ avg $)$ and its temporal linear trends are represented in Fig. 3 and Table 1 using data from 124 monitoring sites distributed nationwide in 46 cities for the past $12 \mathrm{yr}$ period. The spatial map of climatological daily average $\mathrm{NO}_{2}\left(\mathrm{NO}_{2}\right.$ avg $)$ is also shown in Fig. 3 . In Table 1, the cities are categorized into three geographical groups: 16 coastal cities, 14 inland cities, and 16 cities in the Seoul Metropolitan Area (SMA). We separated the SMA cities from the other two groups since the SMA is the largest source region of anthropogenic $\mathrm{O}_{3}$ precursors in South Korea. The SMA occupies only $11.8 \%\left(11745 \mathrm{~km}^{2}\right)$ of the national area, but has $49 \%$ (25.4 million) of the total population and $45 \%$ (8.1 million) of total vehicles in South Korea. It is estimated that approximately $27 \%(0.29 \mathrm{Mt})$ of total $\mathrm{NO}_{\mathrm{x}}$ emissions and $34 \%(0.30 \mathrm{Mt})$ of the volatile organic compound (VOC) emissions in South Korea were from the SMA in 2010 (KMOE, 2013). Therefore, the climatological $\mathrm{NO}_{2}$ avg concentration in the SMA is much higher than that in other regions (Fig. 3b).

In general, $\mathrm{O}_{3}$ concentrations are high at the coastal cities, low at the inland cities, and lowest at the SMA cities in South Korea. Along with Table 1, Fig. 3a shows that the 12 yr aver- age of $\mathrm{O}_{3 \text { avg }}$ is high at the southern coastal cities such as Jinhae (31.3 ppbv), Mokpo (30.3 ppbv), and Yeosu (28.1 ppbv), with the highest value at Jeju (32.6 ppbv), and low at the inland metropolitan cities such as Daegu (19.8 ppbv), Gwangju (20.5 ppbv), and Daejeon (20.7 ppbv), with lowest values at the SMA cities including Seoul (17.1 ppbv), Incheon (19.0 ppbv) and Anyang (16.8 ppbv).

Compared to the regional background concentration of $35-45 \mathrm{ppbv}$ at five background measurement sites around South Korea (KMOE, 2012), the averaged $\mathrm{O}_{3}$ concentrations in the SMA and inland metropolitan cities are much lower while those at the coastal cities are close to the regional background levels. In comparison with Fig. 3b, Fig. 3a shows that relatively lower $\mathrm{O}_{3}$ avg regions are well consistent with relatively higher $\mathrm{NO}_{2}$ avg regions. Substantial emissions of anthropogenic NO in the SMA and other inland metropolitan cities lead to $\mathrm{NO}_{\mathrm{x}}$ titration effects even in the absence of photochemical reactions during the night, and thus the averaged $\mathrm{O}_{3}$ concentrations are depressed by 10-20 ppbv lower than the regional background concentration (Ghim and Chang, 2000). A recent modeling study by Jin et al. (2012) has suggested that the maximum $\mathrm{O}_{3}$ concentrations in the SMA, especially in Seoul and Incheon, are VOC-limited. In the coastal region, however, low emissions of $\mathrm{NO}$ with dilution by the strong winds weaken the titration effect and result in the high $\mathrm{O}_{3}$ concentrations. The dynamic effect of land-sea breeze is another possible factor of the high $\mathrm{O}_{3}$ levels at the coastal cities. Oh et al. (2006) showed that a near-stagnant wind condition at the development of sea breeze temporarily contains $\mathrm{O}_{3}$ precursors carried by the offshore land breeze 

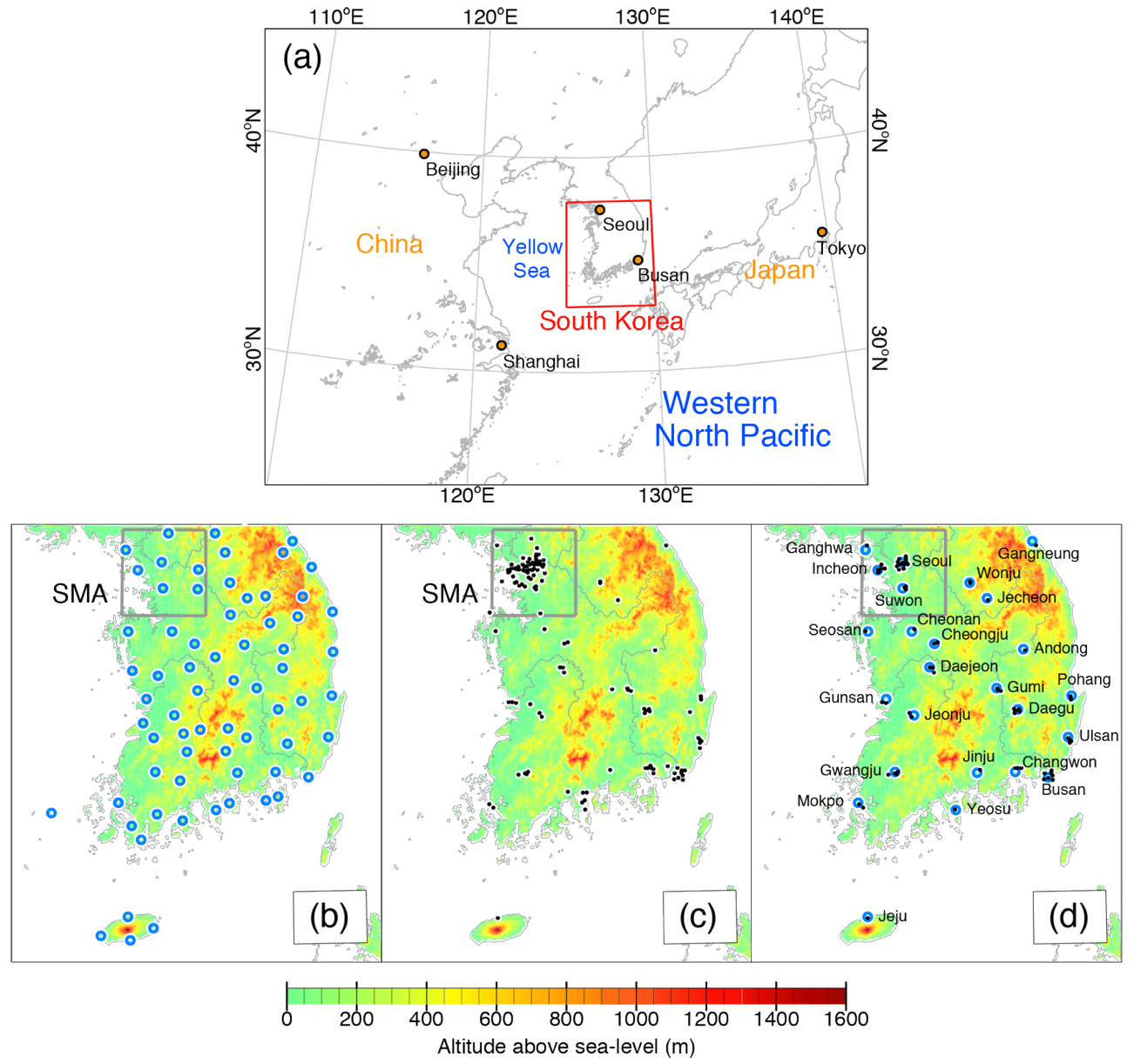

Figure 2. (a) Geographical location of South Korea, (b) 72 weather stations of the Korea Meteorological Administration (KMA) as blue circles, (c) 124 air quality monitoring sites of the National Institute of Environmental Research (NIER) as black dots, and (d) 72 air quality monitoring sites of NIER, which are located within $10 \mathrm{~km}$ from 25 weather stations of KMA over the South Korean domain.

(a) $\mathrm{O}_{3}$ avg climatology

(b) $\mathrm{NO}_{2 \text { avg }}$ climatology

(c) $\mathrm{O}_{3}$ avg trend

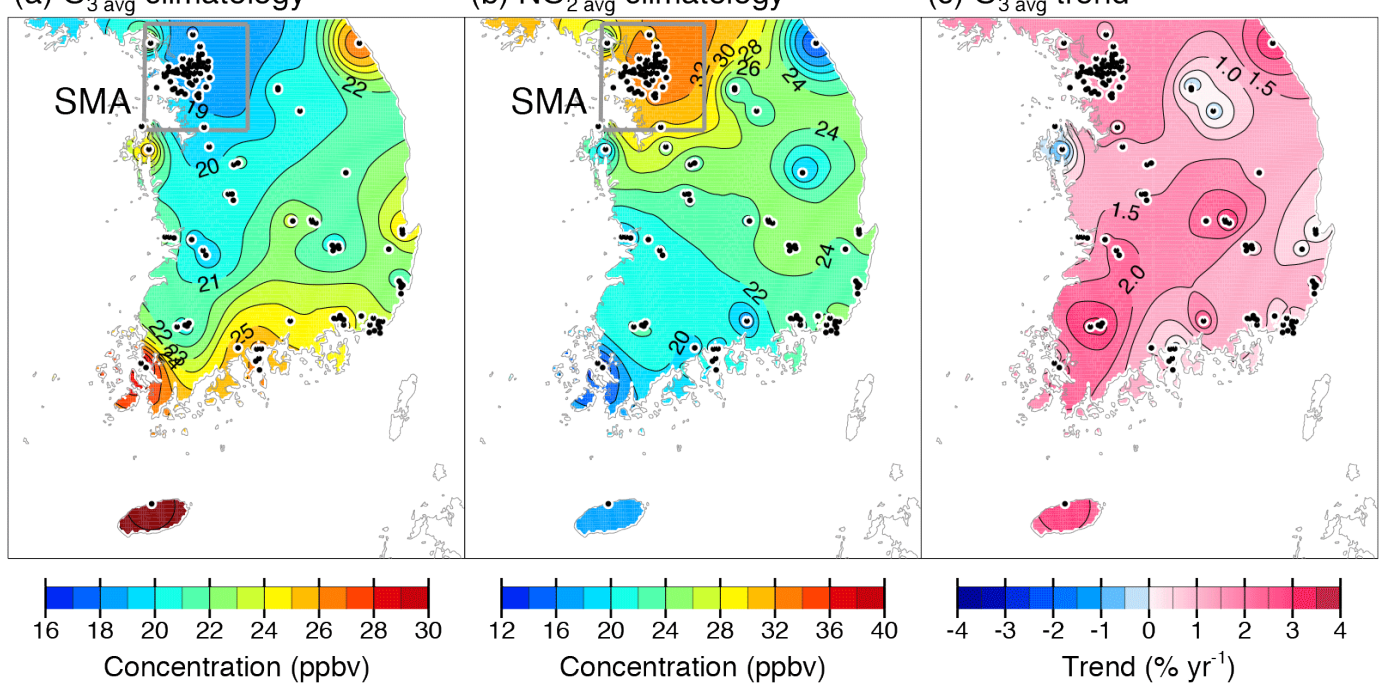

Figure 3. Spatial distributions of $12 \mathrm{yr}$ averaged concentrations of (a) daily average $\mathrm{O}_{3}\left(\mathrm{O}_{3}\right.$ avg $)$, (b) daily average nitrogen dioxide $\left(\mathrm{NO} \mathrm{O}_{2}\right.$ avg $)$, and (c) temporal linear trends of $\mathrm{O}_{3}$ avg for the period 1999-2010 using data from 124 air quality monitoring sites (black dots) of NIER. 
Table 1. $12 \mathrm{yr}$ averaged concentrations and temporal linear trends of daily average $\mathrm{O}_{3}\left(\mathrm{O}_{3}\right.$ avg $)$ at 46 cities over South Korea for the period 1999-2010. The cities are categorized into three groups: 16 coastal cities, 14 inland cities, and 16 cities in the SMA.

\begin{tabular}{|c|c|c|c|c|c|c|c|c|c|c|c|}
\hline $\begin{array}{l}\text { Coastal } \\
\text { region }\end{array}$ & $\begin{array}{l}\text { City } \\
\text { code }\end{array}$ & $\begin{array}{l}\mathrm{O}_{3 \text { avg }} \\
\text { (ppbv) }\end{array}$ & $\begin{array}{r}\text { Trend } \\
\left(\% \mathrm{yr}^{-1}\right)\end{array}$ & $\begin{array}{l}\text { Inland } \\
\text { region }\end{array}$ & $\begin{array}{l}\text { City } \\
\text { code }\end{array}$ & $\begin{array}{l}\mathrm{O}_{3 \text { avg }} \\
\text { (ppbv) }\end{array}$ & $\begin{array}{r}\text { Trend } \\
\left(\% \mathrm{yr}^{-1}\right)\end{array}$ & SMA & $\begin{array}{l}\text { City } \\
\text { code }\end{array}$ & $\begin{array}{l}\mathrm{O}_{3 \text { avg }} \\
\text { (ppbv) }\end{array}$ & $\begin{array}{r}\text { Trend } \\
\left(\% \mathrm{yr}^{-1}\right)\end{array}$ \\
\hline Busan* & BS & 23.2 & 0.65 & Andong & $\mathrm{AD}$ & 22.0 & 1.35 & Ansan & - & 20.5 & 1.81 \\
\hline Changwon & $\mathrm{CW}$ & 25.1 & 1.62 & Cheonan & $\mathrm{CN}$ & 18.7 & 0.72 & Anyang & - & 16.8 & 0.67 \\
\hline Gangneung & GN & 26.5 & 2.61 & Cheongju & $\mathrm{CJ}$ & 21.0 & 1.25 & Bucheon & - & 18.3 & 1.71 \\
\hline Gimhae & - & 24.4 & -0.05 & Daegu* & DG & 19.8 & 0.77 & Ganghwa & $\mathrm{GH}$ & 30.9 & 1.12 \\
\hline Gunsan & GS & 22.5 & 0.66 & Daejeon* & DJ & 20.7 & 1.21 & Goyang & - & 19.1 & 0.77 \\
\hline Gwangyang & - & 28.1 & -1.28 & Gimcheon & - & 24.4 & 2.36 & Gunpo & - & 19.6 & -0.86 \\
\hline Jeju & $\mathrm{JJ} 1$ & 32.6 & 2.59 & Gumi & GM & 22.6 & 3.70 & Guri & - & 18.1 & -0.83 \\
\hline Jinhae & - & 31.3 & 1.03 & Gwangju* & GJ & 20.5 & 3.50 & Gwacheon & - & 17.6 & -1.25 \\
\hline Masan & - & 25.2 & 0.85 & Gyeongju & - & 22.1 & -0.27 & Gwangmyeong & - & 18.0 & 0.41 \\
\hline Mokpo & MP & 30.3 & -0.21 & Iksan & - & 17.7 & 2.64 & Incheon* & IC & 19.0 & 1.45 \\
\hline Pohang & $\mathrm{PH}$ & 25.7 & 0.01 & Jecheon & $\mathrm{JC}$ & 21.0 & -0.21 & Pyeongtaek & - & 19.9 & 2.75 \\
\hline Seosan & SS & 27.5 & -1.67 & Jeonju & $\mathrm{JJ} 2$ & 18.9 & 2.55 & Seongnam & - & 18.8 & 0.66 \\
\hline Suncheon & - & 25.7 & 0.92 & Jinju & $\mathrm{JJ} 3$ & 24.0 & 2.54 & Seoul* & SU & 17.1 & 2.82 \\
\hline Ulsan* & US & 21.5 & 1.61 & Wonju & WJ & 20.7 & -0.24 & Siheung & - & 21.0 & 2.29 \\
\hline Yeongam & - & 28.6 & 3.58 & & & & & Suwon & SW & 19.3 & 1.86 \\
\hline Yeosu & YS & 28.1 & 1.18 & & & & & Uijeongbu & - & 19.9 & 1.46 \\
\hline \multicolumn{2}{|c|}{ Coastal averages } & 26.6 & 0.88 & \multicolumn{2}{|c|}{ Inland averages } & 21.0 & 1.56 & \multicolumn{2}{|c|}{ SMA averages } & 19.6 & 1.05 \\
\hline \multicolumn{2}{|c|}{$\begin{array}{l}\text { Nationwide } \\
\text { averages }\end{array}$} & 22.5 & 1.15 & & & & & & & & \\
\hline
\end{tabular}

* Major metropolitan cities in South Korea (Seoul, Busan, Daegu, Incheon, Gwangju, Daejeon, and Ulsan).

during the night, and following photochemical reactions at midday produces $\mathrm{O}_{3}$. The relationship between $\mathrm{O}_{3}$ and wind speed and direction will be shown in Sects. 3.2 and 3.5, respectively.

In terms of temporal trends, the surface $\mathrm{O}_{3}$ concentrations in South Korea have generally increased for the past $12 \mathrm{yr}$ as shown in Fig. 3c and Table 1. The averaged temporal linear trend of $\mathrm{O}_{3}$ avg at 46 cities nationwide is $+1.15 \% \mathrm{yr}^{-1}$ $\left(+0.26 \mathrm{ppbv} \mathrm{yr}^{-1}\right)$, which is comparable with observed increasing trends of approximately $+0.5-2 \% \mathrm{yr}^{-1}$ in various regions in the Northern Hemisphere (Vingarzan, 2004). Compared with previous studies in East Asia, the overall increasing trend of $\mathrm{O}_{3}$ in South Korea is smaller than recent increasing trends over China of $+1.1 \mathrm{ppbv} \mathrm{yr}^{-1}$ in Beijing for the period 2001-2006 (Tang et al., 2009) and $+0.58 \mathrm{ppbv} \mathrm{yr}^{-1}$ in Hong Kong for the period 1994-2007 (Wang et al., 2009) but slightly larger than increasing trend over Japanese populated areas of $+0.18 \mathrm{ppbv} \mathrm{yr}^{-1}$ for 1996 2005 (Chatani and Sudo, 2011).

Several factors that could influence the overall increase of $\mathrm{O}_{3}$ over East Asia were suggested by the following previous studies. Recently, Zhao et al. (2013) have estimated that the $\mathrm{NO}_{\mathrm{x}}$ emissions in China increased rapidly from $11.0 \mathrm{Mt}$ in 1995 to $26.1 \mathrm{Mt}$ in 2010 , mainly due to the fast growth of energy consumption. The $\mathrm{NO}_{\mathrm{x}}$ and VOC emissions in South Korea also increased in the early 2000s. The estimated anthropogenic $\mathrm{NO}_{\mathrm{x}}$ and $\mathrm{VOC}$ emissions are 1.10 and $0.74 \mathrm{Mt}$ in 1999 but 1.35 and $0.87 \mathrm{Mt}$ in 2006, respectively (KMOE,
2013). Tanimoto et al. (2009) suggested that the $\mathrm{O}_{3}$ increase results from such recently increased anthropogenic precursor emissions in East Asia.

However, model sensitivity simulations in Chatani and Sudo (2011) indicate that the changes in East Asian emissions can explain only $30 \%$ of the $\mathrm{O}_{3}$ trend. They have suggested the long-term variations in meteorological fields as a possible important factor although further studies are required. In particular, it is well known that insolation and temperature are important meteorological factors in $\mathrm{O}_{3}$ variation. While insolation directly affects $\mathrm{O}_{3}$ production through photochemical reactions, increased temperature affects net $\mathrm{O}_{3}$ production rather indirectly by increasing biogenic hydrocarbon emissions, hydroxyl radical $(\mathrm{OH})$ with more evaporation, and $\mathrm{NO}_{\mathrm{x}}$ and $\mathrm{HO}_{\mathrm{x}}$ radicals by thermal decomposition of the peroxyacetyl nitrate (PAN) reservoir (Sillman and Samson, 1995; Olszyna et al., 1997; Racherla and Adams, 2006; Dawson et al., 2007). Therefore, the $\mathrm{O}_{3}$ increasing trend in Fig. $3 \mathrm{c}$ is possibly affected by changes in meteorological variables.

Figure 4 shows temporal linear trends of daily average temperature $(T)$ and insolation (SI). Despite the spatial discrepancy between trends of $\mathrm{O}_{3}$ (Fig. 3c) and meteorological variables (Fig. 4), both temperature and insolation have generally increased in South Korea for the past $12 \mathrm{yr}$. The spatial mean of the temporal linear trend in temperature at 72 weather stations nationwide is approximately $+0.09^{\circ} \mathrm{C} \mathrm{yr}^{-1}$, which is much higher than $+0.03{ }^{\circ} \mathrm{C} \mathrm{yr}^{-1}$ for the Northern 
(a) T trend

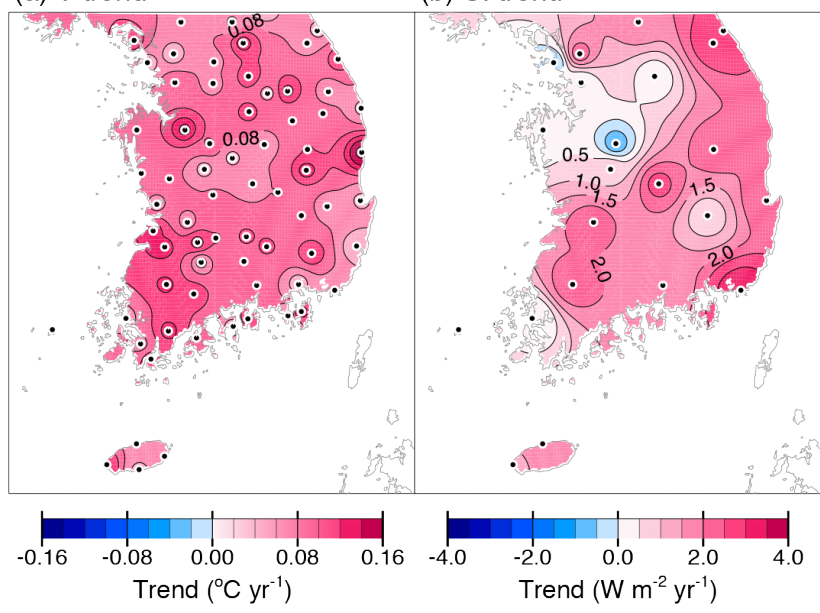

Figure 4. Spatial distributions of temporal linear trends of (a) daily average $T$ and (b) daily average SI for the period 1999-2010 using data from 72 and 22 weather stations (black dots) of KMA, respectively.

Hemispheric land surface air temperature for the period 1979-2005 (IPCC, 2007). This highly increasing trend of temperature in South Korea is probably due to the urban heat island effect with rapid urbanization. The averaged temporal linear trend of insolation at 22 weather stations nationwide is about $+1.47 \mathrm{~W} \mathrm{~m}^{-2} \mathrm{yr}^{-1}$ despite the decreasing phase of solar cycle during the 2000s. This is possibly caused by the reduction in particulate matter emissions due to enhanced environment regulation in South Korea during the recent decade (KMOE, 2012).

Although $\mathrm{O}_{3}$ and related meteorological variables such as temperature and insolation have recently increased in South Korea, the spatial patterns of their temporal trends do not show clear similarity. In addition, the spatial distribution of $\mathrm{O}_{3}$ trends is rather inhomogeneous even on a metropolitan scale. For instance, Table 1 shows a wide range of $\mathrm{O}_{3}$ trends among the SMA cities from $-1.25 \% \mathrm{yr}^{-1}$ at Gwacheon to $+2.82 \% \mathrm{yr}^{-1}$ at Seoul. The spatial inhomogeneity in $\mathrm{O}_{3}$ trends and the trend differences among $\mathrm{O}_{3}$, temperature, and insolation imply that the long-term $\mathrm{O}_{3}$ trends in South Korea are not only affected by changes in meteorological conditions but also influenced by changes in local precursor emissions or transport of $\mathrm{O}_{3}$ and its precursors. The local effects of precursor emissions on the long-term changes in $\mathrm{O}_{3}$ are further examined in Sect. 3.6.

\subsection{Relationships between $\mathrm{O}_{3}$ and meteorological variables}

A multiple linear regression model is here adopted to explain relationships between $\mathrm{O}_{38 \mathrm{~h}}$ and each of key meteorological variables such as $T_{\max }$, SI, TD, PS, WS, and RH. To exclude day-to-day short-term fluctuations or white noises from the original time series, $\mathrm{KZ}_{29,3}$ was applied to each variable before the regression process and yielded baselines of each variable. As a result of the multiple linear regression, coefficients of determination $\left(R^{2}\right)$ between baselines of $\mathrm{O}_{38 \mathrm{~h}}$ and each meteorological variable, as well as adjusted $R^{2}$ for the multiple linear regression models, were calculated for 72 air quality monitoring sites distributed in 25 cities nationwide and summarized in Table 2. Combined meteorological effects on $\mathrm{O}_{3}$ variations in each city are represented by adjusted $R^{2}$, which adjusts for the number of predictors with consideration of the degrees of freedom. The nationwide average of adjusted $R^{2}$ is 0.51 and that of $R^{2}$ is 0.50 for SI, 0.29 for PS, 0.22 for $T_{\max }, 0.14$ for TD, 0.05 for RH, and 0.03 for WS, respectively. In South Korea, SI, $T_{\max }$, and TD generally show positive correlations with $\mathrm{O}_{3}$ levels while PS is negatively correlated with $\mathrm{O}_{3}$ variations. Since the short-term variability in each variable is excluded, the negative correlation between $\mathrm{O}_{3}$ and PS is related to their seasonal cycle rather than continuously changing weather system of high and low. PS in South Korea, located on the continental east coast, is mostly affected by the cold continental high pressure air mass during the winter, when the $\mathrm{O}_{3}$ concentrations are lowest. However, WS and RH show weak correlations with $\mathrm{O}_{3}$ variations.

The spatial distributions of $R^{2}$ for $T_{\max }$ and SI, as well as the adjusted $R^{2}$ for the combined meteorological effects, are represented in Fig. 5. Both Fig. 5a and b show a common spatial pattern with high correlations at the inland and SMA cities and low correlations at the coastal cities. For instance, the average $R^{2}$ value with $T_{\max }$ for the coastal cities is only 0.07 , which is much smaller than 0.36 for the SMA cities and 0.30 for the inland cities. Also, the average $R^{2}$ values with SI are 0.60 for the SMA cities and 0.58 for the inland cities, but 0.35 for the coastal cities. Despite the similar pattern between Fig. 5a and b, the $R^{2}$ values of SI are much higher than those of $T_{\max }$ because temperature affects net $\mathrm{O}_{3}$ production rather indirectly compared to the direct influence of insolation on $\mathrm{O}_{3}$ levels by photochemical production (Dawson et al., 2007, and references therein). The apparent $R^{2}$ differences among the three regions indicate that temporal variations of $\mathrm{O}_{3}$ at the SMA and inland cities are much more sensitive to SI and $T_{\max }$ than those at the coastal cities. The low dependence of $\mathrm{O}_{3}$ on $T_{\max }$ and SI at the coastal cities means that the photochemical reactions of precursors are less important for determining $\mathrm{O}_{3}$ levels there compared to the SMA and inland cities.

The meteorological effects on $\mathrm{O}_{3}$ at the inland, coastal, and SMA cities are also examined by daily minimum $\mathrm{O}_{3}$ $\left(\mathrm{O}_{3 \text { min }}\right)$. As represented in Fig. 6a and Table 3, the $\mathrm{O}_{3 \min }$ is high near the coast, low at the inland cities, and lowest in the SMA. In the polluted urban area, the $\mathrm{O}_{3}$ concentration reaches near-zero minima during the night since $\mathrm{O}_{3}$ is reduced by $\mathrm{NO}_{\mathrm{x}}$ titration, a nocturnal $\mathrm{NO}_{\mathrm{y}}$ chemical process related to nitrate formation, and dry deposition in the absence of photochemical production. However, in the coastal region where the $\mathrm{NO}_{\mathrm{x}}$ concentrations are low (Fig. 3b), the 
Table 2. Coefficients of determination $\left(R^{2}\right)$ between the baseline of daily maximum $8 \mathrm{~h}$ average $\mathrm{O}_{3}\left(\mathrm{O}_{3} 8 \mathrm{~h}\right)$ and baselines of six meteorological variables $\left(T_{\max }\right.$, SI, TD, PS, WS, and RH) at 25 cities over South Korea for the period 1999-2010. Adjusted $R^{2}$ (Adj. $R^{2}$ ) between the baseline of $\mathrm{O}_{38 \mathrm{~h}}$ and combined meteorological effects $\left(a_{0}+\sum_{i} a_{i} \operatorname{MET}_{\mathrm{BL}}(t)_{i}\right)$ are also represented. The cities are categorized into three groups: 10 coastal cities, 11 inland cities, and 4 cities in the SMA. Numbers in bold fonts indicate correlations significant at the $95 \%$ level or higher.

\begin{tabular}{|c|c|c|c|c|c|c|c|c|c|}
\hline & \multirow[t]{2}{*}{ Cities } & \multirow{2}{*}{$\begin{array}{l}\text { City } \\
\text { code }\end{array}$} & \multicolumn{6}{|c|}{ Coefficients of determination $\left(R^{2}\right)$} & \multirow{2}{*}{$\begin{array}{l}\text { Adj. } R^{2} \\
\operatorname{MET}_{\mathrm{BL}}\end{array}$} \\
\hline & & & $T_{\max }$ & SI & TD & PS & WS & $\mathrm{RH}$ & \\
\hline \multirow[t]{11}{*}{ Coastal region } & Busan $^{1}$ & BS & 0.147 & 0.366 & 0.139 & $0.222^{2}$ & 0.014 & 0.135 & 0.408 \\
\hline & Changwon & $\mathrm{CW}$ & 0.224 & $\mathrm{n} / \mathrm{a}$ & 0.179 & $\mathbf{0 . 3 3 5} 5^{2}$ & $0.001^{2}$ & 0.138 & 0.533 \\
\hline & Gangneung & GN & 0.013 & 0.480 & 0.000 & $0.072^{2}$ & 0.014 & $0.008^{2}$ & 0.449 \\
\hline & Gunsan & GS & 0.032 & $\mathrm{n} / \mathrm{a}$ & 0.017 & $0.047^{2}$ & 0.002 & $0.003^{2}$ & 0.164 \\
\hline & Jeju & $\mathrm{JJ} 1$ & $0.028^{2}$ & 0.080 & $0.069^{2}$ & 0.004 & 0.009 & $0.141^{2}$ & $\mathbf{0 . 3 3 7}$ \\
\hline & Mokpo & MP & 0.012 & 0.263 & 0.004 & $0.038^{2}$ & $0.047^{2}$ & $0.043^{2}$ & 0.427 \\
\hline & Pohang & $\mathrm{PH}$ & 0.034 & 0.404 & 0.014 & $0.102^{2}$ & $0.043^{2}$ & 0.003 & 0.398 \\
\hline & Seosan & SS & 0.059 & 0.495 & 0.021 & $\mathbf{0 . 1 3 5}^{2}$ & 0.001 & $0.049^{2}$ & 0.506 \\
\hline & Ulsan $^{1}$ & US & 0.071 & $\mathrm{n} / \mathrm{a}$ & 0.046 & $0.107^{2}$ & $0.035^{2}$ & 0.023 & 0.186 \\
\hline & Yeosu & YS & 0.093 & $\mathrm{n} / \mathrm{a}$ & 0.061 & $0.140^{2}$ & $0.002^{2}$ & 0.024 & 0.251 \\
\hline & Averages & & 0.071 & 0.348 & 0.055 & $0.120^{2}$ & 0.017 & 0.057 & 0.366 \\
\hline \multirow[t]{12}{*}{ Inland region } & Andong & $\mathrm{AD}$ & 0.269 & 0.544 & 0.128 & $0.379^{2}$ & 0.004 & $0.026^{2}$ & 0.628 \\
\hline & Cheonan & $\mathrm{CN}$ & 0.400 & $\mathrm{n} / \mathrm{a}$ & 0.263 & $0.479^{2}$ & $0.003^{2}$ & $0.056^{2}$ & 0.674 \\
\hline & Cheongju & $\mathrm{CJ}$ & 0.387 & 0.666 & 0.219 & $\mathbf{0 . 4 4 3}^{2}$ & 0.052 & $0.053^{2}$ & 0.674 \\
\hline & Daegu $^{1}$ & DG & 0.381 & 0.621 & 0.224 & $\mathbf{0 . 4 9 3}^{2}$ & $0.002^{2}$ & 0.016 & 0.703 \\
\hline & Daejeon $^{1}$ & DJ & 0.312 & 0.721 & 0.160 & $0.408^{2}$ & 0.089 & $0.062^{2}$ & 0.724 \\
\hline & Gumi & GM & 0.244 & $\mathrm{n} / \mathrm{a}$ & 0.116 & $\mathbf{0 . 3 6 1}{ }^{2}$ & $0.009^{2}$ & $0.038^{2}$ & 0.563 \\
\hline & Gwangju ${ }^{1}$ & GJ & 0.274 & 0.502 & 0.159 & $0.315^{2}$ & 0.015 & $0.005^{2}$ & 0.570 \\
\hline & Jecheon & $\mathrm{JC}$ & 0.258 & $\mathrm{n} / \mathrm{a}$ & 0.137 & $0.365^{2}$ & 0.012 & $0.108^{2}$ & 0.589 \\
\hline & Jeonju & $\mathrm{JJ} 2$ & 0.134 & 0.434 & 0.060 & $0.179^{2}$ & $0.008^{2}$ & $0.038^{2}$ & 0.404 \\
\hline & Jinju & $\mathrm{JJ} 3$ & 0.199 & 0.413 & 0.129 & $\mathbf{0 . 2 3 8 ^ { 2 }}$ & 0.000 & 0.012 & 0.396 \\
\hline & Wonju & WJ & 0.476 & 0.767 & 0.312 & $\mathbf{0 . 5 7 3}^{2}$ & 0.069 & $0.018^{2}$ & 0.799 \\
\hline & Averages & & 0.303 & 0.584 & 0.173 & $0.385^{2}$ & 0.024 & $0.039^{2}$ & 0.611 \\
\hline \multirow[t]{5}{*}{ SMA } & Ganghwa & $\mathrm{GH}$ & 0.204 & $\mathrm{n} / \mathrm{a}$ & 0.158 & $0.274^{2}$ & 0.190 & 0.025 & 0.389 \\
\hline & Incheon $^{1}$ & IC & 0.310 & 0.501 & 0.250 & $0.411^{2}$ & $0.019^{2}$ & 0.097 & 0.577 \\
\hline & Seoul $^{1}$ & SU & 0.419 & 0.580 & 0.318 & $\mathbf{0 . 5 3 1}^{2}$ & $0.009^{2}$ & 0.045 & 0.693 \\
\hline & Suwon & SW & 0.525 & 0.703 & 0.422 & $0.640^{2}$ & 0.009 & 0.080 & 0.818 \\
\hline & Averages & & 0.364 & 0.595 & 0.287 & $0.464^{2}$ & 0.057 & 0.062 & 0.619 \\
\hline \multicolumn{3}{|c|}{ Nationwide averages } & 0.220 & 0.502 & 0.144 & $0.292^{2}$ & 0.026 & $0.050^{2}$ & 0.514 \\
\hline
\end{tabular}

lower titration and nitrate formation at nighttime lead to the higher $\mathrm{O}_{3}$ min levels. In addition, transport of $\mathrm{O}_{3}$ from the regional background could also keep high levels of $\mathrm{O}_{3}$ during the night (Ghim and Chang, 2000). Frequency distributions of $\mathrm{O}_{3}$ concentrations in previous studies suggested that $\mathrm{O}_{3}$ levels at the coastal cities such as Gangneung, Jeju, Mokpo, Seosan, and Yeosu are affected by the background $\mathrm{O}_{3}$ transport, unlike Seoul where the effect of local precursor emissions is dominant (Ghim and Chang, 2000; Ghim, 2000). Therefore, combined effects of the low $\mathrm{NO}_{\mathrm{x}}$ levels and trans- port of the regional background $\mathrm{O}_{3}$ influence the high $\mathrm{O}_{3 \text { min }}$ near the coast.

Compared to the spatial distribution of $R^{2}$ between baselines of $\mathrm{O}_{38 \mathrm{~h}}$ and $T_{\max }$ or $\mathrm{SI}$ (Fig. 5a, b), $\mathrm{O}_{3 \text { min }}$ distribution in Fig. 6a shows high $\mathrm{O}_{3}$ min at the coastal cities where the $R^{2}$ is low and low $\mathrm{O}_{3 \text { min }}$ at the inland cities where the $R^{2}$ is high. These opposite patterns suggest that the meteorological effects on the $\mathrm{O}_{3}$ production are negatively correlated with $\mathrm{O}_{3 \text { min }}$ for the South Korean cities. The clear negative correlations are also shown in scatter plots (Fig. 6b, c). In both scatter plots, the three geographical groups of cities (blue for 
(a) $\mathrm{T}_{\max B L}$ and $\left[\mathrm{O}_{3 \mathrm{BL}}\right]$

(b) $\mathrm{SI}_{\mathrm{BL}}$ and $\left[\mathrm{O}_{3 \mathrm{BL}}\right]$

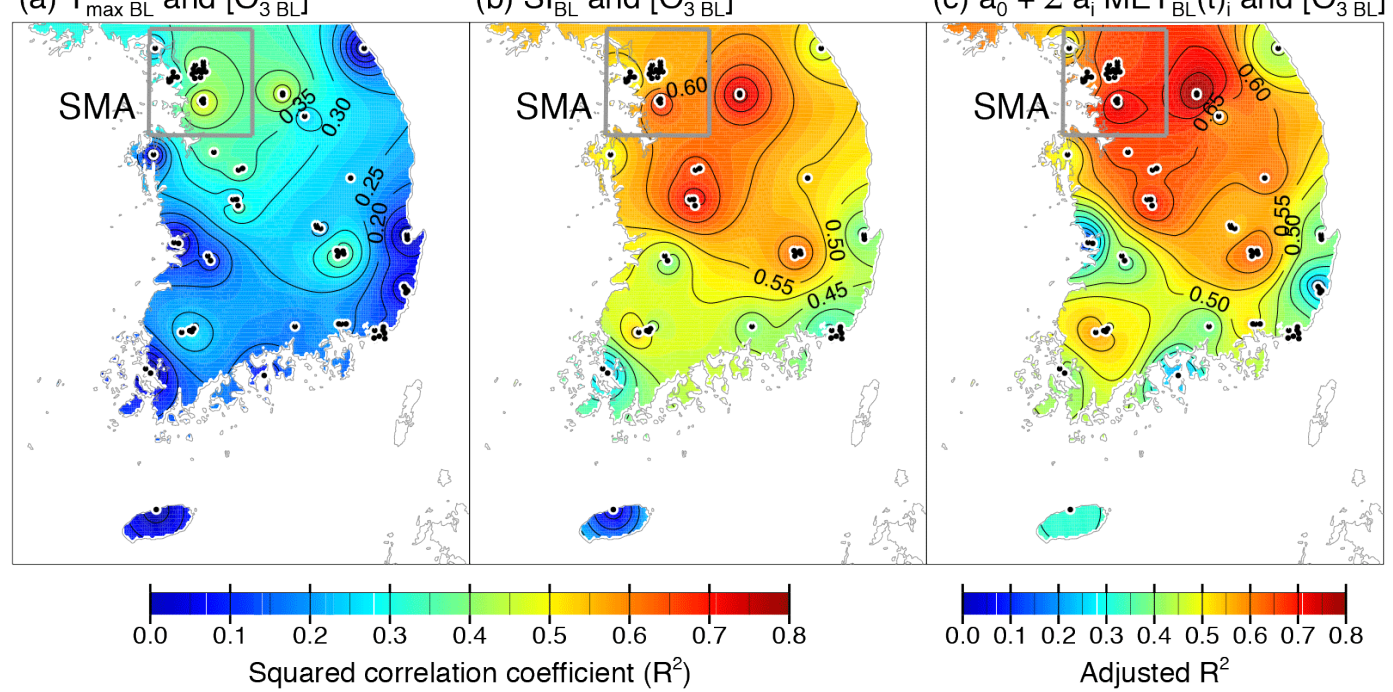

Figure 5. Spatial distributions of $R^{2}$ between baselines of $\mathrm{O}_{38 \mathrm{~h}}\left(\left[\mathrm{O}_{3 \mathrm{BL}}\right]\right)$ and (a) daily maximum temperature $\left(T_{\mathrm{max}} \mathrm{BL}\right)$ and $(\mathbf{b})$ surface insolation $\left(\mathrm{SI}_{\mathrm{BL}}\right)$. Black dots represent 72 air quality monitoring sites of NIER. (c) Spatial distribution of adjusted $R^{2}$ between $\left[\mathrm{O}_{3 \mathrm{BL}}\right]$ and combined meteorological effects $\left(a_{0}+\sum_{i} a_{i} \operatorname{MET}_{\mathrm{BL}}(t)_{i}\right)$.

(a) $\mathrm{O}_{3 \text { min }}$ climatology

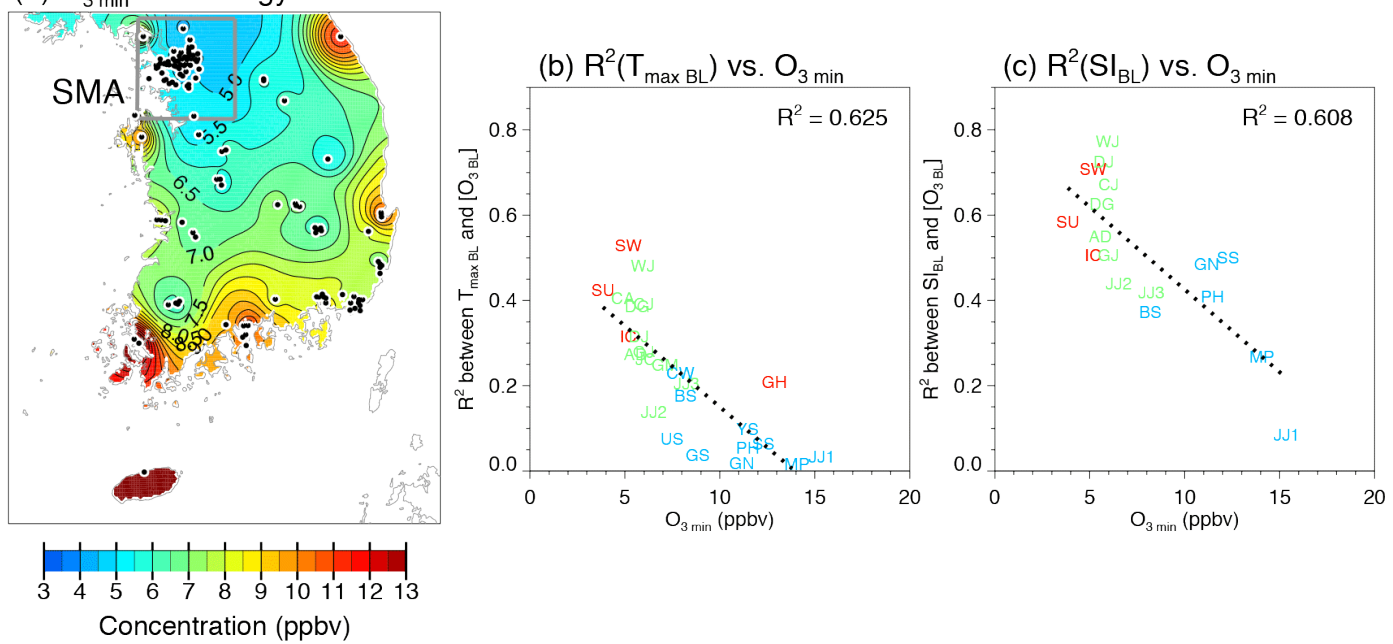

Figure 6. (a) Spatial distribution of $12 \mathrm{yr}$ averaged concentrations of $\mathrm{O}_{3 \mathrm{~min}}$ for the period 1999-2010 using data from 124 air quality monitoring sites (black dots) of NIER. (b) Scatter plot of $R^{2}$ between $\left[\mathrm{O}_{3 \mathrm{BL}}\right]$ and $T_{\max \mathrm{BL}} \mathrm{vs}$. $\mathrm{O}_{3 \min }$ at 25 cities. (c) Scatter plot of $R^{2}$ between $\left[\mathrm{O}_{3 \mathrm{BL}}\right]$ and $\mathrm{SI}_{\mathrm{BL}}$ vs. $\mathrm{O}_{3}$ min at 17 cities. City codes in red, green, and blue indicate the SMA, inland, and coastal cities, respectively.

the coastal cities, green for the inland cities and red for SMA) are well separated. Several industrial or metropolitan cities in the coastal region such as Changwon (CW), Busan (BS), and Ulsan (US) have a relatively low $\mathrm{O}_{3 \text { min }}$ compared to the other coastal cities. Larger $\mathrm{NO}_{\mathrm{x}}$ emissions in these southeastern coastal cities (Fig. 3b) induce lower $\mathrm{O}_{3 \text { min }}$ levels via $\mathrm{NO}_{\mathrm{x}}$ titration and a nocturnal $\mathrm{NO}_{\mathrm{y}}$ chemical process. Among the SMA cities, however, Ganghwa (GH) has much higher $\mathrm{O}_{3 \text { min }}$ compared to other SMA cities. Ganghwa is a rural county located on the northwestern coast of the SMA. Therefore, both small $\mathrm{NO}_{\mathrm{x}}$ emissions there and transport of regional back- ground $\mathrm{O}_{3}$ from the Yellow Sea affect the characteristics of $\mathrm{O}_{3}$ in Ganghwa.

The different meteorological effects on $\mathrm{O}_{3}$ between the coastal and inland regions are further examined with wind speed. Daily average WS data over South Korea are averaged for $12 \mathrm{yr}$. The $12 \mathrm{yr}$ averaged WS is summarized in Table 3 and presented in a spatial map in Fig. 7a, which shows high wind speed in the coastal region and low wind speed in the inland region. Figure $7 \mathrm{~b}$ and $\mathrm{c}$ show that the averaged wind speeds at 25 cities are positively correlated with $\mathrm{O}_{3}$ min and negatively correlated with the $R^{2}$ between $\mathrm{O}_{3}$ and $T_{\max }$. In 
Table 3. $12 \mathrm{yr}$ averaged of daily minimum $\mathrm{O}_{3}\left(\mathrm{O}_{3} \min \right)$ concentrations and daily average WS at 46 cities over South Korea for the period 1999-2010. The cities are categorized into three groups: 16 coastal cities, 14 inland cities, and 16 cities in the SMA.

\begin{tabular}{|c|c|c|c|c|c|c|c|c|c|c|c|}
\hline $\begin{array}{l}\text { Coastal } \\
\text { region }\end{array}$ & $\begin{array}{l}\text { City } \\
\text { code }\end{array}$ & $\begin{array}{l}\mathrm{O}_{3 \min } \\
(\mathrm{ppbv})\end{array}$ & $\begin{array}{r}\text { WS } \\
\left(\mathrm{m} \mathrm{s}^{-1}\right)\end{array}$ & $\begin{array}{l}\text { Inland } \\
\text { region }\end{array}$ & $\begin{array}{l}\text { City } \\
\text { code }\end{array}$ & $\begin{array}{l}\mathrm{O}_{3 \min } \\
(\mathrm{ppbv})\end{array}$ & $\begin{array}{r}\text { WS } \\
\left(\mathrm{m} \mathrm{s}^{-1}\right)\end{array}$ & SMA & $\begin{array}{l}\text { City } \\
\text { code }\end{array}$ & $\begin{array}{l}\mathrm{O}_{3 \min } \\
(\mathrm{ppbv})\end{array}$ & $\begin{array}{r}\mathrm{WS} \\
\left(\mathrm{m} \mathrm{s}^{-1}\right)\end{array}$ \\
\hline Busan* & BS & 8.2 & 3.38 & Andong & $\mathrm{AD}$ & 5.6 & 1.61 & Ansan & - & 5.7 & $\mathrm{n} / \mathrm{a}$ \\
\hline Changwon & $\mathrm{CW}$ & 7.9 & 2.01 & Cheonan & $\mathrm{CN}$ & 4.9 & 1.79 & Anyang & - & 3.9 & $\mathrm{n} / \mathrm{a}$ \\
\hline Gangneung & GN & 11.1 & 2.86 & Cheongju & $\mathrm{CJ}$ & 6.0 & 1.70 & Bucheon & - & 5.9 & $\mathrm{n} / \mathrm{a}$ \\
\hline Gimhae & - & 7.7 & $\mathrm{n} / \mathrm{a}$ & Daegu* & DG & 5.6 & 2.31 & Ganghwa & $\mathrm{GH}$ & 12.9 & 1.84 \\
\hline Gunsan & GS & 8.8 & 3.07 & Daejeon* & DJ & 5.7 & 1.96 & Goyang & - & 6.2 & $\mathrm{n} / \mathrm{a}$ \\
\hline Gwangyang & - & 12.9 & $\mathrm{n} / \mathrm{a}$ & Gimcheon & - & 7.9 & $\mathrm{n} / \mathrm{a}$ & Gunpo & - & 4.8 & $\mathrm{n} / \mathrm{a}$ \\
\hline Jeju & $\mathrm{JJ} 1$ & 15.4 & 3.31 & Gumi & GM & 7.1 & 1.53 & Guri & - & 4.4 & $\mathrm{n} / \mathrm{a}$ \\
\hline Jinhae & - & 13.3 & $\mathrm{n} / \mathrm{a}$ & Gwangju* & GJ & 6.0 & 2.07 & Gwacheon & - & 4.8 & $\mathrm{n} / \mathrm{a}$ \\
\hline Masan & - & 8.6 & $\mathrm{n} / \mathrm{a}$ & Gyeongju & - & 7.9 & $\mathrm{n} / \mathrm{a}$ & Gwangmyeong & - & 5.6 & $\mathrm{n} / \mathrm{a}$ \\
\hline Mokpo & MP & 14.1 & 3.64 & Iksan & - & 6.4 & $\mathrm{n} / \mathrm{a}$ & Incheon* & IC & 5.2 & 2.69 \\
\hline Pohang & $\mathrm{PH}$ & 11.5 & 2.68 & Jecheon & $\mathrm{JC}$ & 6.1 & 1.51 & Pyeongtaek & - & 4.9 & $\mathrm{n} / \mathrm{a}$ \\
\hline Seosan & SS & 12.3 & 2.66 & Jeonju & $\mathrm{JJ} 2$ & 6.5 & 2.02 & Seongnam & - & 5.8 & $\mathrm{n} / \mathrm{a}$ \\
\hline Suncheon & - & 9.4 & 1.16 & Jinju & $\mathrm{JJ} 3$ & 8.2 & 1.37 & Seoul* ${ }^{*}$ & SU & 3.8 & 2.27 \\
\hline Ulsan* & US & 7.5 & 2.12 & Wonju & WJ & 5.9 & 1.09 & Siheung & - & 6.6 & $\mathrm{n} / \mathrm{a}$ \\
\hline Yeongam & - & 13.7 & $\mathrm{n} / \mathrm{a}$ & & & & & Suwon & SW & 5.2 & 1.86 \\
\hline Yeosu & YS & 11.5 & 4.30 & & & & & Uijeongbu & - & 4.9 & $\mathrm{n} / \mathrm{a}$ \\
\hline \multicolumn{2}{|c|}{ Coastal averages } & 10.9 & 2.84 & \multicolumn{2}{|c|}{ Inland averages } & 6.4 & 1.72 & \multicolumn{2}{|c|}{ SMA averages } & 5.6 & 2.17 \\
\hline \multicolumn{2}{|c|}{ Nationwide averages } & 7.7 & 2.26 & & & & & & & & \\
\hline
\end{tabular}

* Major metropolitan cities in South Korea.

$\mathrm{n} / \mathrm{a}$ : not available observations of wind speed.

general, surface mixing and ventilation by high wind speeds reduce the near-surface precursors and thus decrease the photochemical production of $\mathrm{O}_{3}$. Therefore the relationship between high wind speed and high $\mathrm{O}_{3}$ levels in the coastal region is attributable to the transport of background $\mathrm{O}_{3}$. However, the weaker wind speed induces a more effective photochemical reaction through the longer reaction time in stagnant conditions as well as more enhanced aerodynamic resistance to dry deposition (Jacob and Winner, 2009). Therefore, the effects of insolation and temperature on the $\mathrm{O}_{3}$ productions become more important in the inland region where the wind speeds are lower.

\subsection{Probability of $\mathrm{O}_{3}$ exceedances related to temperature}

Evaluating the probability of $\mathrm{O}_{3}$ exceeding the air quality standard in a given range of temperature is useful to speculate about the potential sensitivity of $\mathrm{O}_{3}$ concentrations to climate change (Lin et al., 2001; Jacob and Winner, 2009). Here we calculate the probabilities that $\mathrm{O}_{38 \mathrm{~h}}$ exceeds the Korean air quality standard of $60 \mathrm{ppbv}$ (KMOE, 2012) as a function of the daily maximum temperature $\left(T_{\max }\right)$ for the coastal, inland, and SMA cities. Similar to the analyses in Lin et al. (2001) for the contiguous United States, Fig. 8 shows that the probabilities of $\mathrm{O}_{3}$ exceedances increase with $T_{\max }$ at the inland and SMA cities. For example, the probability of $\mathrm{O}_{3}$ exceedances in the SMA is almost doubled by an increase of about $4{ }^{\circ} \mathrm{C}$ in $T_{\max }$ and reach $27 \%$ at $30^{\circ} \mathrm{C}$. In the coastal region, however, the probability of $\mathrm{O}_{3}$ exceedance increases up to $12-13 \%$ with a $T_{\max }$ change from 10 to $20^{\circ} \mathrm{C}$ and does not increase significantly for $T_{\max }$ above $20^{\circ} \mathrm{C}$. This is consistent with the spatial feature of the meteorological effects on $\mathrm{O}_{3}$ levels, which are high at the inland and SMA cities and low at the coastal cities as described in the previous section. Therefore, the probability of high $\mathrm{O}_{3}$ occurrence will be more sensitive to the future climate change at the inland and SMA cities than at the coastal cities. In the previous modeling study by Boo et al. (2006), $T_{\max }$ over the Korean Peninsula is expected to rise by about $4-5^{\circ} \mathrm{C}$ by the end of $21 \mathrm{st}$ century, due to global warming. This suggests considerable future increases in exceedances of the $\mathrm{O}_{3}$ air quality standard over South Korea, except over coastal regions, in the absence of emission abatement measures.

\subsection{Relative contributions of $\mathrm{O}_{3}$ variations in different timescales}

Surface $\mathrm{O}_{3}$ variation can be decomposed into a short-term component $\left(\left[\mathrm{O}_{3 \mathrm{ST}}\right]\right)$, seasonal component $\left(\left[\mathrm{O}_{3 \text { SEASON }}\right]\right)$, and long-term component $\left(\left[\mathrm{O}_{3 \mathrm{LT}}\right]\right)$ by using the $\mathrm{KZ}$ filter as described in Sect. 2.2. We evaluated relative contributions of each component to the total variance of original time series. Overall, the relative contributions of $\left[\mathrm{O}_{3 \mathrm{LT}}\right]$ in Fig. 9c are much smaller than those of $\left[\mathrm{O}_{3 \mathrm{ST}}\right]$ in Fig. $9 \mathrm{a}$ and $\left[\mathrm{O}_{3}\right.$ SEASON $]$ 
(a) WS climatology

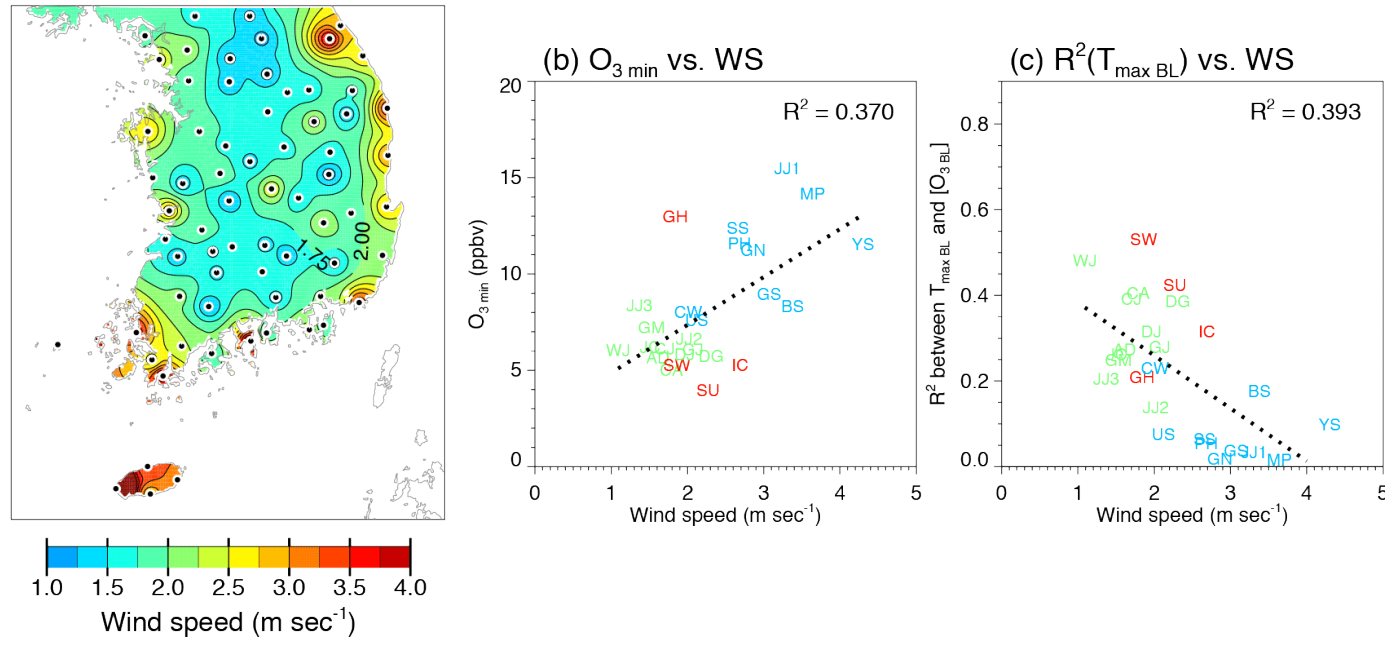

Figure 7. (a) Spatial distribution of $12 \mathrm{yr}$ averaged daily average WS for the period 1999-2010 using data from 72 weather stations (black dots) of KMA. (b) Scatter plot of $\mathrm{O}_{3 \text { min }}$ vs. WS at 25 cities. (c) Scatter plot of $R^{2}$ between $\left[\mathrm{O}_{3}\right.$ BL] and $T_{\max }$ BL vs. WS at 25 cities. City codes in red, green, and blue indicate the SMA, inland, and coastal cities, respectively.

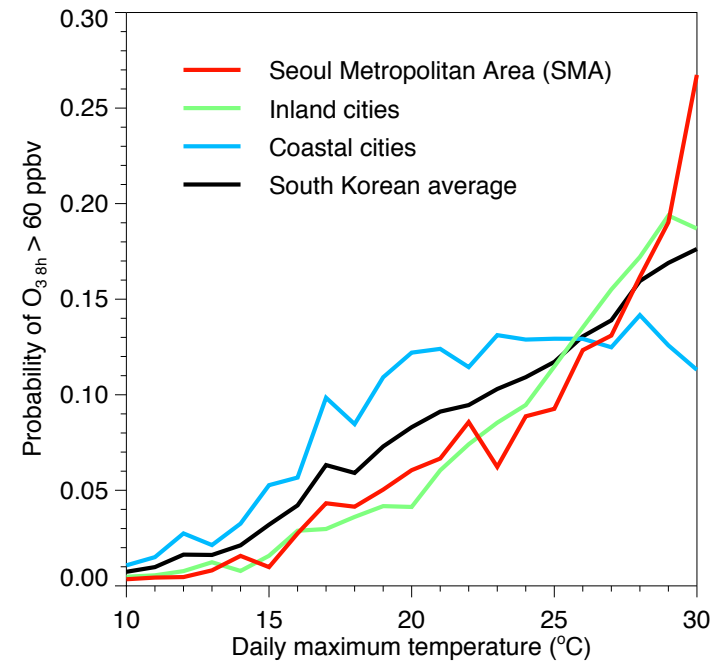

Figure 8. Probabilities of $\mathrm{O}_{3}$ exceedances in the given range of daily maximum temperature $\left(T_{\max }\right)$ that $\mathrm{O}_{38}$ h will exceed the air quality standard of South Korea (60 ppbv).

in $b$ at all cities (Table 4). Therefore, sum of $\left[\mathrm{O}_{3 \mathrm{ST}}\right]$ and $\left[\mathrm{O}_{3 \text { SEASON }}\right]$ account for the most of $\mathrm{O}_{3}$ variations.

In Fig. 9a and b, the relative contributions of $\left[\mathrm{O}_{3 \mathrm{ST}}\right]$ and $\left[\mathrm{O}_{3 \text { SEASON }}\right]$ show a strong negative relationship spatially. The relative contributions of $\left[\mathrm{O}_{3 \mathrm{ST}}\right]$ are generally larger at the coastal cities $(53.1 \%)$ than at the inland cities $(45.9 \%)$, whereas the relative contributions of $\left[\mathrm{O}_{3 \text { SEASON }}\right]$ are smaller at the coastal cities (32.8\%) than at the inland cities (41.9\%).

Since $\left[\mathrm{O}_{3 \mathrm{ST}}\right]$ is related to synoptic-scale weather fluctuations (Rao et al., 1995, 1997), the large relative contributions of $\left[\mathrm{O}_{3 \mathrm{ST}}\right]$ at the coastal cities indicate the stronger effects of the eastward-moving synoptic weather systems there. Interestingly, the highest value of the $\left[\mathrm{O}_{3 \mathrm{ST}}\right]$ contribution appears at a northeastern coastal city, Gangneung. High and steep mountains on the west of Gangneung induce often warm, dry, and strong westerly winds, which is favorable to the clear sky and strong vertical mixing over the region. Since the westerly winds contain the precursors emitted from the SMA, the clear sky condition increases the $\mathrm{O}_{3}$ levels during the daytime. In addition, the strong vertical mixing of high $\mathrm{O}_{3}$ air from the free troposphere compensates the $\mathrm{O}_{3}$ loss by titration during the nighttime. In the easterly winds, however, orographic lift often forms fog or clouds over the region and reduces the photochemical production of $\mathrm{O}_{3}$. Therefore, the combined effects of wind directions related to synoptic weather systems and topography increase the short-term variability of $\mathrm{O}_{3}$ at Gangneung.

However, $\left[\mathrm{O}_{3 \text { SEASON }}\right]$ is driven mainly by the annual cycle of meteorological factors such as insolation or temperature. Therefore, the large relative contributions of $\left[\mathrm{O}_{3 \text { SEASON }}\right]$ at the inland cities are consistent with the higher impacts of temperature and insolation on $\mathrm{O}_{3}$ there (Figs. 5, 9b). The highest and second-highest values of the $\left[\mathrm{O}_{3 \text { SEASON }}\right]$ contribution appear at Andong and Wonju, located in the inland basin. Since the basin topography often traps pollutants and induces large annual ranges of temperature, seasonal variability of $\mathrm{O}_{3}$ at the two cities is larger than that of other inland cities.

$\left[\mathrm{O}_{3 \mathrm{LT}}\right]$ explains less than $10 \%$ of the total variances, but its relative contribution is considerable in the southwestern part of the Korean Peninsula as displayed in Fig. 9c. This is related to a relatively large long-term variability or trend in the region and is further discussed in Sect. 3.6. 
(a) Short-term component

(b) Seasonal component

(c) Long-term component

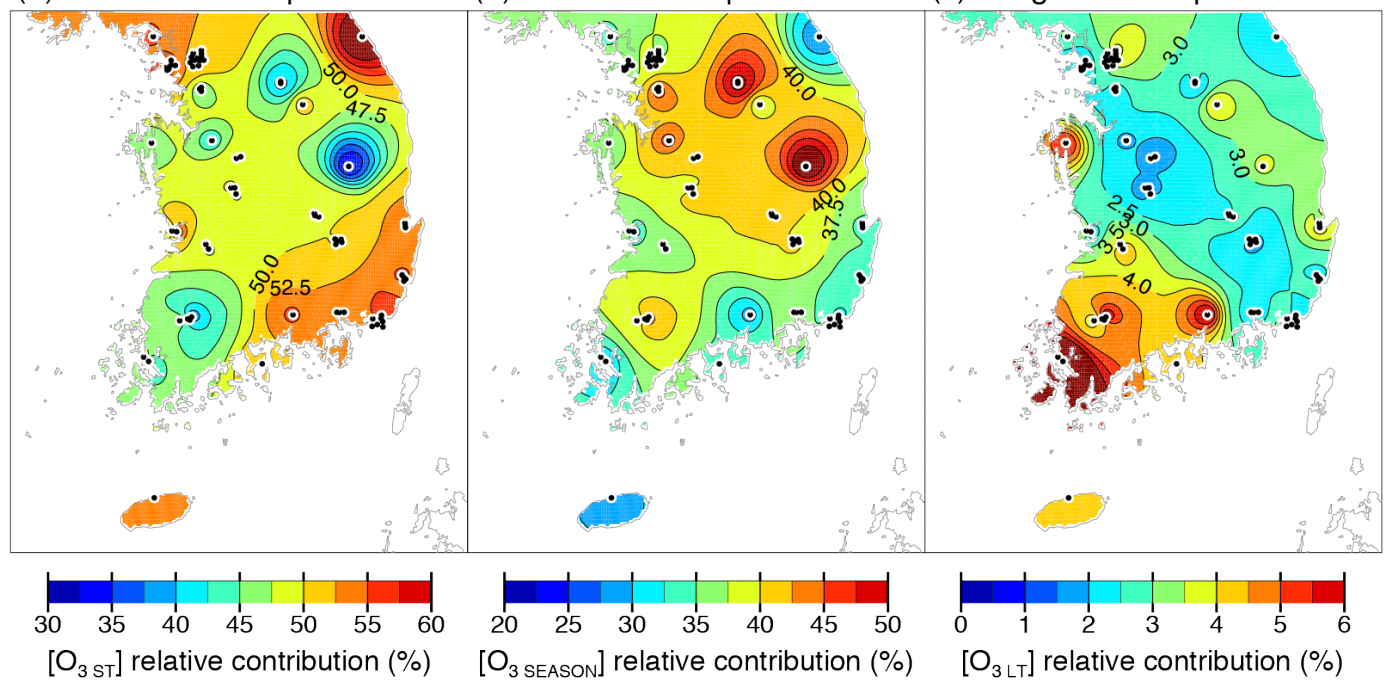

Figure 9. Spatial distributions of relative contributions of the (a) short-term component $\left(\left[\mathrm{O}_{3} \mathrm{ST}\right]\right)$, (b) seasonal component ([O $\left.\mathrm{O}_{3 \mathrm{SEASON}}\right]$ ), and (c) long-term component $\left(\left[\mathrm{O}_{3 \mathrm{LT}}\right]\right)$ to the total variance of original time series $\left(\left[\mathrm{O}_{3}\right]\right)$ using data from 72 air quality monitoring sites (black dots) of NIER. Note that the color scales are all different.

Table 4. Relative contributions $(\%)$ of short-term components ( $\left.\left[\mathrm{O}_{3 \mathrm{ST}}\right]\right)$, seasonal components $\left(\left[\mathrm{O}_{3}\right.\right.$ SEASON $]$ ), and long-term components $\left(\left[\mathrm{O}_{3 \mathrm{LT}}\right]\right)$ to total variance of log-transformed daily maximum $8 \mathrm{~h}$ average $\mathrm{O}_{3}\left(\left[\mathrm{O}_{3}\right]\right)$ at 25 cities over South Korea for the period $1999-2010$. The cities are categorized into three groups: 10 coastal cities, 11 inland cities, and 4 cities in the SMA.

\begin{tabular}{|c|c|c|c|c|c|c|c|c|c|c|c|c|c|c|}
\hline \multirow{2}{*}{$\begin{array}{l}\text { Coastal } \\
\text { region }\end{array}$} & \multirow{2}{*}{$\begin{array}{l}\text { City } \\
\text { code }\end{array}$} & \multicolumn{3}{|c|}{ Relative contributions (\%) } & \multirow{2}{*}{$\begin{array}{l}\text { Inland } \\
\text { region }\end{array}$} & \multirow{2}{*}{$\begin{array}{l}\text { City } \\
\text { code }\end{array}$} & \multicolumn{3}{|c|}{ Relative contributions (\%) } & \multirow[t]{2}{*}{ SMA } & \multirow{2}{*}{$\begin{array}{l}\text { City } \\
\text { code }\end{array}$} & \multicolumn{3}{|c|}{ Relative contributions (\%) } \\
\hline & & {$\left[\mathrm{O}_{3 \mathrm{ST}}\right]$} & {$\left[\mathrm{O}_{3}\right.$ SEASON $]$} & {$\left[\mathrm{O}_{3 \mathrm{LT}}\right]$} & & & {$\left[\mathrm{O}_{3 \mathrm{ST}}\right]$} & {$\left[\mathrm{O}_{3}\right.$ SEASON $]$} & {$\left[\mathrm{O}_{3 \mathrm{LT}}\right]$} & & & {$\left[\mathrm{O}_{3 \mathrm{ST}}\right]$} & {$\left[\mathrm{O}_{3}\right.$ SEASON $]$} & {$\left[\mathrm{O}_{3 \mathrm{LT}}\right]$} \\
\hline Busan* & BS & 56.1 & 32.6 & 2.5 & Andong & $\mathrm{AD}$ & 32.7 & 53.2 & 3.6 & Ganghwa & $\mathrm{GH}$ & 56.2 & 33.1 & 3.2 \\
\hline Changwon & $\mathrm{CW}$ & 53.6 & 36.2 & 2.0 & Cheonan & $\mathrm{CN}$ & 41.5 & 46.5 & 1.8 & Incheon* & IC & 58.7 & 32.7 & 1.5 \\
\hline Gangneung & GN & 62.5 & 29.1 & 2.0 & Cheongju & CJ & 48.3 & 41.7 & 1.3 & Seoul* & SU & 51.8 & 38.2 & 3.8 \\
\hline Gunsan & GS & 52.3 & 34.2 & 2.7 & Daegu* & DG & 50.4 & 41.3 & 1.6 & Suwon & SW & 42.0 & 49.4 & 1.8 \\
\hline Jeju & $\mathrm{JJ} 1$ & 53.8 & 29.2 & 4.3 & Daejeon* & DJ & 49.2 & 40.5 & 1.5 & & & & & \\
\hline Mokpo & MP & 46.1 & 30.9 & 8.5 & Gumi & GM & 48.2 & 42.0 & 2.7 & & & & & \\
\hline Pohang & $\mathrm{PH}$ & 53.9 & 34.4 & 4.1 & Gwangju* & GJ & 41.5 & 41.3 & 4.8 & & & & & \\
\hline Seosan & SS & 45.1 & 35.6 & 5.3 & Jecheon & $\mathrm{JC}$ & 50.8 & 38.6 & 4.0 & & & & & \\
\hline Ulsan* & US & 55.5 & 32.1 & 2.5 & Jeonju & $\mathrm{JJ} 2$ & 47.4 & 36.1 & 4.2 & & & & & \\
\hline Yeosu & YS & 52.2 & 34.1 & 4.3 & Jinju & $\mathrm{JJ} 3$ & 55.5 & 29.2 & 6.2 & & & & & \\
\hline & & & & & Wonju & WJ & 39.5 & 50.8 & 2.3 & & & & & \\
\hline \multicolumn{2}{|c|}{ Coastal averages } & 53.1 & 32.8 & 3.8 & \multicolumn{2}{|c|}{ Inland averages } & 45.9 & 41.9 & 3.1 & \multicolumn{2}{|c|}{ SMA averages } & 52.2 & 38.3 & 2.6 \\
\hline \multicolumn{2}{|c|}{ Nationwide averages } & 49.8 & 37.7 & 3.3 & & & & & & & & & & \\
\hline
\end{tabular}

\subsection{Short-term variation of $\mathrm{O}_{3}$ related to wind direction}

The short-term components of $\mathrm{O}_{3}\left(\left[\mathrm{O}_{3 \mathrm{ST}}\right]\right)$ account for a large fraction of total $\mathrm{O}_{3}$ variation over South Korea. In Table 4 , relative contributions of $\left[\mathrm{O}_{3 \mathrm{ST}}\right]$ range from 32.7 to $62.5 \%$ and have a nationwide average of $49.8 \%$. Therefore, it is no wonder that high $\mathrm{O}_{3}$ episodes are mostly determined by day-to-day fluctuation of $\left[\mathrm{O}_{3 \mathrm{ST}}\right]$. One considerable factor influencing the short-term variation of $\mathrm{O}_{3}$ is wind. Shin et al. (2012) displayed $\left[\mathrm{O}_{3 \mathrm{ST}}\right]$ on the wind speed-direction domain and showed that the effects of episodic long-range transport and local precursor emission on the ambient $\mathrm{O}_{3}$ concentrations could be qualitatively separated from $\left[\mathrm{O}_{3 \mathrm{ST}}\right]$.
We here further investigate the transport effect on the short-term variations of $\mathrm{O}_{3}$ and the frequency of high $\mathrm{O}_{3}$ episodes using $\exp \left[\mathrm{O}_{3 \mathrm{ST}}\right]$ and WDs. As described in Sect. 2.2, $\exp \left[\mathrm{O}_{3 \mathrm{ST}}\right]$ is a ratio of the raw $\mathrm{O}_{38 \mathrm{~h}}$ concentration to its baseline concentration in ppbv $\left(\exp \left[\mathrm{O}_{3 \mathrm{BL}}\right]\right)$. Thus, the $\mathrm{O}_{38 \mathrm{~h}}$ concentration is higher than the baseline $\mathrm{O}_{38 \mathrm{~h}}$ concentration when $\exp \left[\mathrm{O}_{3 \mathrm{ST}}\right]>1$. We classified every single value of $\exp \left[\mathrm{O}_{3 \mathrm{ST}}\right]$ with the eight cardinal WDs during the months of frequent high $\mathrm{O}_{3}$ events (May-October) at all available monitoring sites within each city. The probabilities of $\exp \left[\mathrm{O}_{3 \mathrm{ST}}\right]>1$ for each WD were compared with the probabilities of exceeding the South Korean air quality standard of $60 \mathrm{ppbv}$ for $\mathrm{O}_{38 \mathrm{~h}}$. 

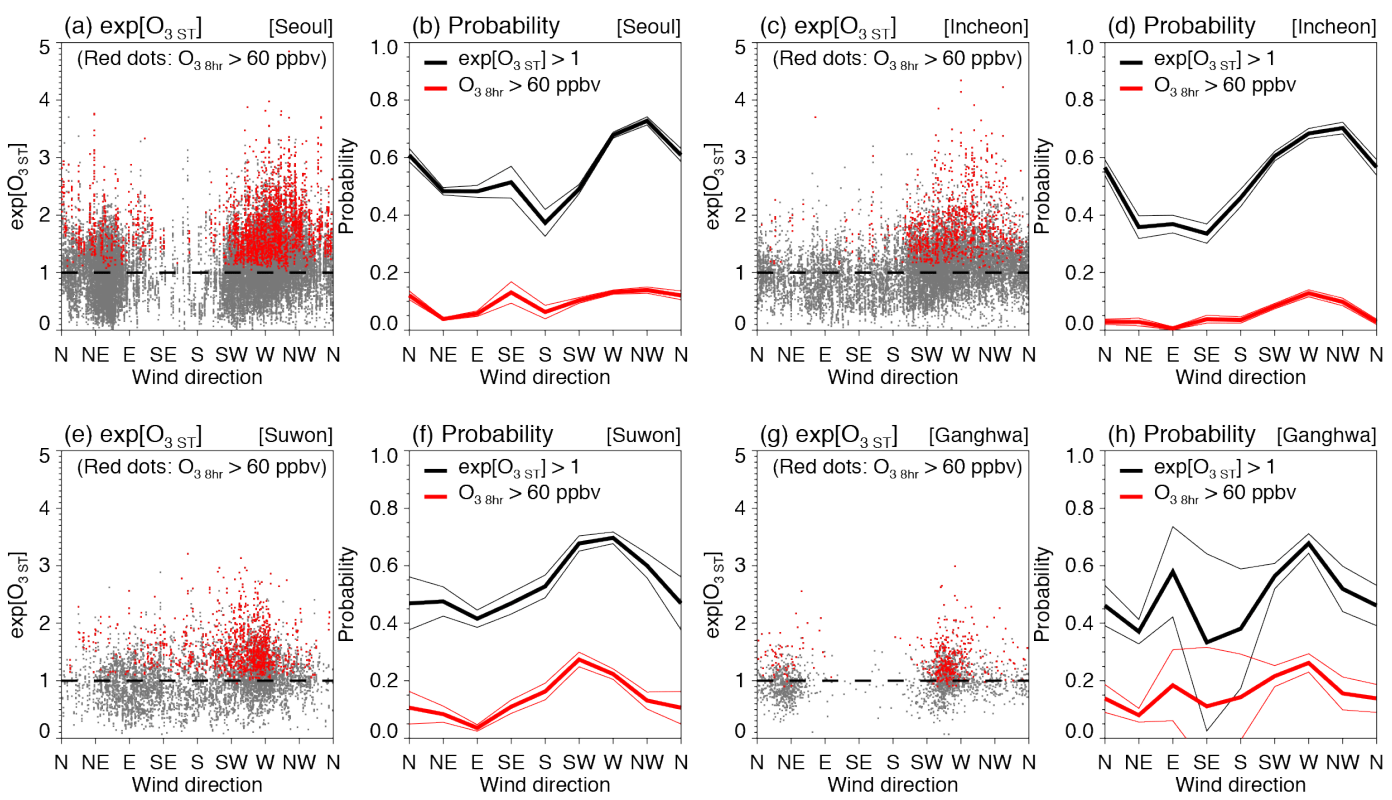

Figure 10. Relationships between WD and exponentials of short-term components $\left(\exp \left[\mathrm{O}_{3 \mathrm{ST}}\right]\right)$ during the months of frequent high $\mathrm{O}_{3}$ events (May-October) at Seoul (a-b), Incheon (c-d), Suwon (e-f), and Ganghwa (g-h) in the SMA are represented in scatter plots of exp[O $\left.\mathrm{O}_{3 \mathrm{ST}}\right]$ vs. WD (a, c, e, and g) and probabilities of $\mathrm{O}_{3}$ exceedances in each WD (b, d, f, and h). Red dots in scatter plots denote high $\mathrm{O}_{3}$ episodes in which the daily maximum $8 \mathrm{~h}$ average $\mathrm{O}_{3}\left(\mathrm{O}_{3} \mathrm{~h}\right)$ will exceed the air quality standard of South Korea $(60 \mathrm{ppbv})$. Dashed lines in scatter plots denote the reference of $\exp \left[\mathrm{O}_{3 \mathrm{ST}}\right]=1$. Probabilities of $\exp \left[\mathrm{O}_{3 \mathrm{ST}}\right]>1$ and $\mathrm{O}_{38 \mathrm{~h}}>60 \mathrm{ppbv}$ in each WD are represented as black thick lines and red thick lines, respectively. The black and red thin lines represent the $95 \%$ of confidence intervals for each probability. We used $\mathrm{O}_{3}$ data from 12 sites in Seoul, 6 sites in Incheon, 3 sites in Suwon, and 1 site in Ganghwa.

Figure 10 shows $\exp \left[\mathrm{O}_{3 \mathrm{ST}}\right]$ in the SMA cities (Seoul, Incheon, Suwon, and Ganghwa) with probabilities of $\exp \left[\mathrm{O}_{3 \mathrm{ST}}\right]>1$ and $\mathrm{O}_{38 \mathrm{~h}}>60 \mathrm{ppbv}$ for each WD. In Seoul, high $\mathrm{O}_{3}$ episodes occur mostly during northwesterly winds although westerly and northeasterly winds predominate during the months of frequent high $\mathrm{O}_{3}$ events (Fig. 10a, b). The high probability of high $\mathrm{O}_{3}$ in northwesterly winds in Seoul is similar to those in other neighboring cities in the SMA, where the high probability also occurs during northwesterly winds in Incheon located in the west of Seoul (Fig. 10c, d), and during westerly winds in Suwon in the south of Seoul (Fig. 10e, f), and in Ganghwa in the northwest of Seoul (Fig. 10g, h).

The sea-mountain breeze can explain the prevalence of high $\mathrm{O}_{3}$ episodes under westerly or northwesterly winds in the SMA. In the western coast of the SMA, there are many thermoelectric power plants (see triangles in Figs. 11 and 12) and industrial complexes, which directly emit a large amount of $\mathrm{O}_{3}$ precursors. Heavy inland and maritime transportation in those regions is also an important source of $\mathrm{NO}_{\mathrm{x}}$ and hydrocarbon emissions. Since the SMA is surrounded by the Yellow Sea in the west and a mountainous region in the east (see Fig. 1), the westerly sea breeze is well developed under $\mathrm{O}_{3}$-conducive meteorological conditions such as high temperature and strong insolation with low wind speed (Ghim and Chang, 2000; Ghim et al., 2001). In addition, locally emitted precursors and transported background $\mathrm{O}_{3}$ from the west are trapped in the SMA due to the westerly sea breeze and the mountainous terrain in the east of the SMA. Therefore, the $\mathrm{O}_{3}$ concentrations in the SMA increase in such $\mathrm{O}_{3}$-conducive meteorological conditions with near-westerly winds.

Another factor to increase the high $\mathrm{O}_{3}$ probabilities in the near-westerly winds is long-range transport of $\mathrm{O}_{3}$ and its precursors from China. For example, Ghim et al. (2001) reported some high $\mathrm{O}_{3}$ cases in the SMA, which result from the transport of $\mathrm{O}_{3}$-rich air with strong westerly wind at dawn under overcast conditions. Oh et al. (2010) also showed that the elevated layer of high $\mathrm{O}_{3}$ concentration over the SMA is associated with the long-range transport of $\mathrm{O}_{3}$ from eastern China. As the mixing layer thickens over the SMA, the $\mathrm{O}_{3}$ concentration can increase by up to $25 \%$ via the vertical down-mixing process (Oh et al., 2010). Recently, Kim et al. (2012) showed that westerly winds also transport $\mathrm{O}_{3}$ precursors such as $\mathrm{NO}_{2}$ and carbon monoxide $(\mathrm{CO})$ from China to South Korea.

Interestingly, the high $\mathrm{O}_{3}$ probability in Ganghwa (Fig. 10g, h) shows a bimodal distribution with another peak in easterly wind. Considering that Ganghwa is a rural county on the northwestern coast of the SMA, the double peak of high $\mathrm{O}_{3}$ probability in easterly and westerly winds shows the effects of both local- and long-range transport. 


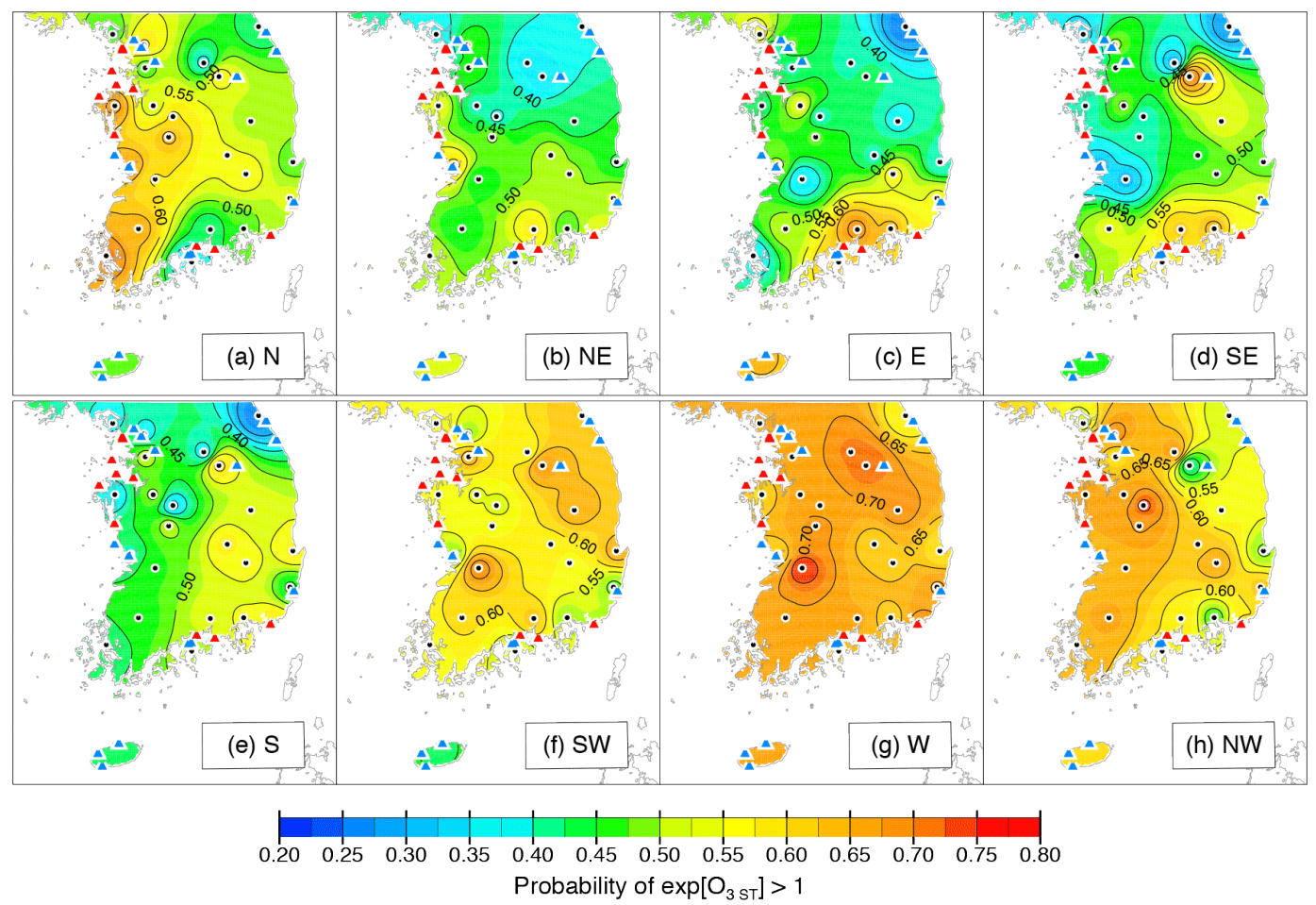

Figure 11. Spatial distributions of probabilities that exponentials of the short-term components will exceed $1\left(\exp \left[\mathrm{O}_{3} \mathrm{ST}\right]>1\right)$ for each WD: (a) northerly (N), (b) northeasterly (NE), (c) easterly (E), (d) southeasterly (SE), (e) southerly (S), (f) southwesterly (SW), (g) westerly (W), and (h) northwesterly (NW), respectively. Black dots denote 25 weather stations of KMA and triangles denote 26 major thermoelectric power plants in South Korea (blue triangle $<1000 \mathrm{MW}$, red triangles $\geq 1000 \mathrm{MW}$ ).

We extended the above $\exp \left[\mathrm{O}_{3 \mathrm{ST}}\right]$ and WD analysis to 25 cities in South Korea. The nationwide view of the high $\mathrm{O}_{3}$ probabilities is represented by the probabilities of $\exp \left[\mathrm{O}_{3 \mathrm{ST}}\right]>1$ and $\mathrm{O}_{38 \mathrm{~h}}>60 \mathrm{ppbv}$ by each wind direction during the months of frequent high $\mathrm{O}_{3}$ events (MayOctober). Figures 11 and 12 show spatial maps of the probabilities of $\exp \left[\mathrm{O}_{3 \mathrm{ST}}\right]>1$ and $\mathrm{O}_{38 \mathrm{~h}}>60 \mathrm{ppbv}$, respectively. As indicators of major precursor emission point sources, we marked 26 of major thermoelectric power plants with triangles on the map. In general, most of the thermoelectric power plants are located in the western coast of the SMA and southeastern coastal region of the Korean Peninsula. Thermoelectric power plants are important sources of $\mathrm{NO}_{\mathrm{x}}$ in South Korea, accounting for $13 \%(0.14 \mathrm{Mt})$ of total $\mathrm{NO}_{\mathrm{x}}$ emissions nationwide (KMOE, 2013). Considering that industrial complexes over South Korea are mostly concentrated near the power plants, the area with triangles in Figs. 11 and 12 represents major sources of $\mathrm{O}_{3}$ precursors.

In Figs. 11 and 12, both probabilities of $\exp \left[\mathrm{O}_{3 \mathrm{ST}}\right]>1$ and $\mathrm{O}_{38 \mathrm{~h}}>60 \mathrm{ppbv}$ are generally high on a national scale during the near-westerly wind conditions (Figs. 11f-h, 12fh). The prevailing westerly wind of the synoptic-scale flow transports $\mathrm{O}_{3}$ and its precursors from China to South Korea and thus increases the probability of high $\mathrm{O}_{3}$ episodes as well as high $\mathrm{O}_{3}$ concentrations. However, on a local scale, the high-probability regions of high $\mathrm{O}_{3}$ correspond to those downwind of the thermoelectric power plants. For example, the high probabilities of high $\mathrm{O}_{3}$ in the southeastern part of South Korea, downwind of power plants along the southeastern coast, also appear even during the easterly or southerly winds (Figs. 11c-e, 12c-e). Therefore, the spatial features of the high $\mathrm{O}_{3}$ probabilities for each wind direction could be associated with both the local effect of precursor emissions and long-range transport from the continent.

\subsection{Long-term variation of $\mathrm{O}_{3}$ and local precursor emissions}

The temporal linear trend of baseline $\left(\left[\mathrm{O}_{3} \mathrm{BL}\right]\right)$ is almost the same as that of the original time series since the shortterm component $\left(\left[\mathrm{O}_{3 \mathrm{ST}}\right]\right)$ is nearly detrended. Therefore, the $\mathrm{O}_{3}$ trend can be represented as a sum of the seasonal component $\left(\left[\mathrm{O}_{3 \text { SEASON }}\right]\right)$ and long-term component $\left(\left[\mathrm{O}_{3 \mathrm{LT}}\right]\right)$ trends. The spatial trend distributions of $\left[\mathrm{O}_{3 \mathrm{BL}}\right]$ and its two separated components of seasonal and long-term components are shown in Fig. 13. It is noted that the period used in Fig. 13 is shorter than the total period of original data because of truncation effect in the KZ filter process. The longterm component obtained by the $\mathrm{KZ}$ filter of $\mathrm{KZ}_{365,3}$ loses 546 days at the beginning and end of the original time series. 


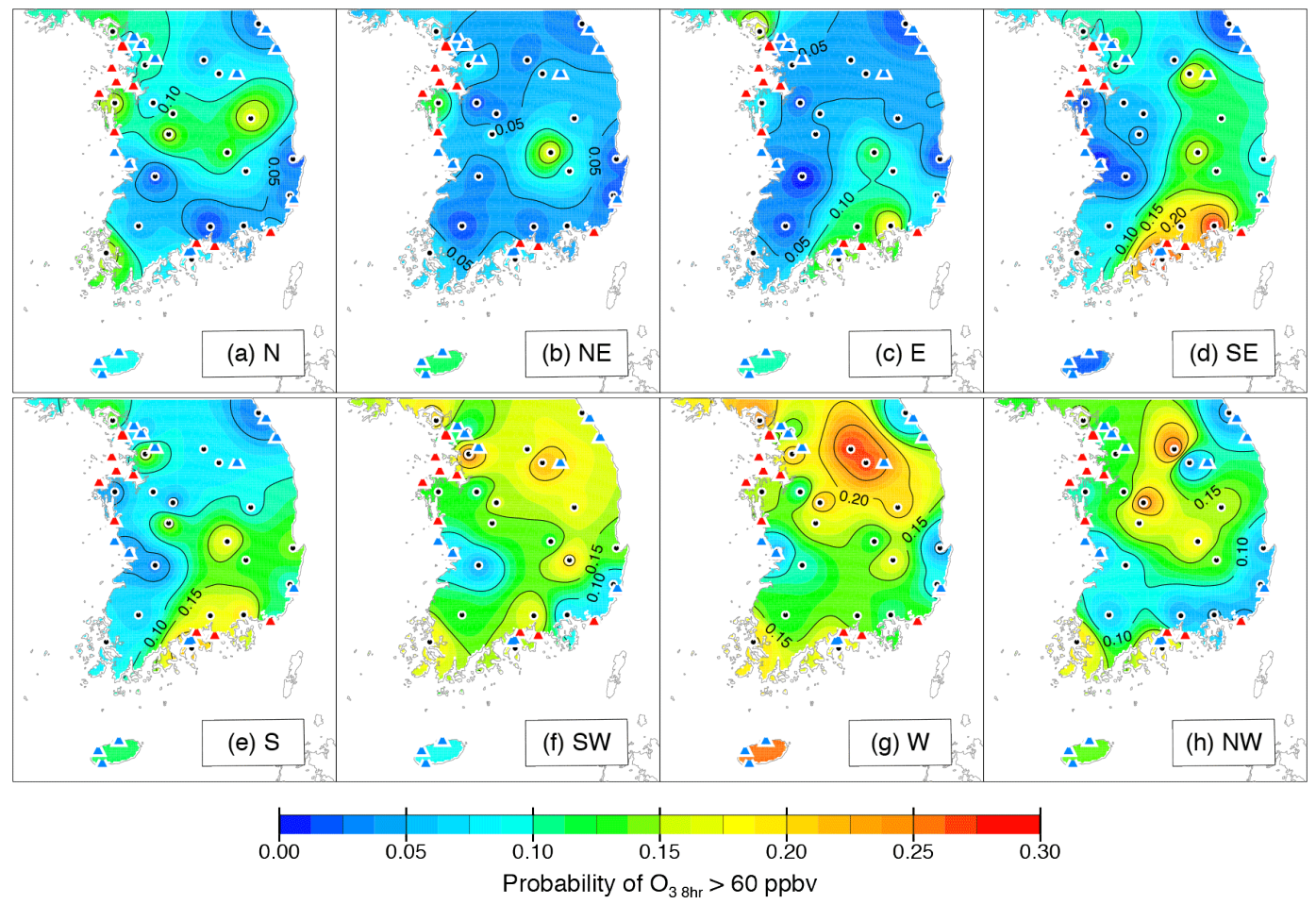

Figure 12. Spatial distributions of probabilities that the daily maximum $8 \mathrm{~h}$ average $\mathrm{O}_{3}\left(\mathrm{O}_{3} 8 \mathrm{~h}\right)$ will exceed the air quality standard of South Korea (60 ppbv) for each WD: (a) N,(b) NE, (c) E, (d) SE, (e) S, (f) SW, (g) W, and (h) NW, respectively. Black dots denote 25 weather stations of KMA and triangles denote 26 major thermoelectric power plants in South Korea (blue triangle $<1000 \mathrm{MW}$, red triangles $\geq 1000 \mathrm{MW}$ ).

The increasing trends of $\mathrm{O}_{3}$ are generally high in the SMA and southwestern region and low in the southeastern coastal region of the Korean Peninsula (Fig. 13a). This spatial inhomogeneity of the $\mathrm{O}_{3}$ trends over South Korea is mainly caused by the long-term component trends (Fig. 13c) rather than the seasonal component trend (Fig. 13b). Therefore, the large spatial variability in local precursor emissions induced the spatial inhomogeneity of $\mathrm{O}_{3}$ trends in South Korea. However, a relatively homogeneous distribution of the seasonal component trends implies that meteorological influences on the long-term changes in $\mathrm{O}_{3}$ have little regional dependence nationwide.

Since the spatially inhomogeneous $\mathrm{O}_{3}$ trends are related to the local precursor emissions, we also tried to investigate their relationship with $\mathrm{NO}_{2}$ measurement data. To detect temporally synchronous and spatially coupled patterns between the long-term variations of $\mathrm{O}_{3}$ and $\mathrm{NO}_{2}$, we applied the SVD to $\left[\mathrm{O}_{3 \mathrm{LT}}\right]$ and the long-term component of $\mathrm{NO}_{2}\left(\left[\mathrm{NO}_{2 \mathrm{LT}}\right]\right)$. [ $\left[\mathrm{NO}_{2 \mathrm{LT}}\right]$ was simply obtained by applying the $\mathrm{KZ}$ filter of $\mathrm{KZ}_{365,3}$ to the log-transformed $\mathrm{NO}_{2}$ time series. The SVD is usually applied to two combined space-time data fields, based on the computation of a temporal crosscovariance matrix between two data fields. The SVD identifies coupled spatial patterns and their temporal variations, with each pair of spatial patterns explaining a fraction of the squared covariance between the two space-time data sets. The squared covariance fraction (SCF) is largest in the first pair (mode) of the patterns, and each succeeding mode has a maximum SCF that is unexplained by the previous modes.

The first three leading SVD modes (singular vectors) of the coupled $\mathrm{O}_{3}$ and $\mathrm{NO}_{2}$ long-term components account for the SCF with $94.6 \%$ of the total, of which the first, second, and third modes are 63.7, 23.6, and 7.3\%, respectively. Figure 14 displays the expansion coefficients (coupled spatial patterns) and their time series of the first mode along with a spatial map of the $\left[\mathrm{NO}_{2} \mathrm{LT}\right]$ trends. The dominant first mode of the $\mathrm{O}_{3}$ and $\mathrm{NO}_{2}$ long-term components (Fig. 14a, b) is very similar to the spatial distributions of $\left[\mathrm{O}_{3 \mathrm{LT}}\right]$ trends (Fig. 13c) and $\left[\mathrm{NO}_{2 \mathrm{LT}}\right]$ trends (Fig. 14c), respectively. In Fig. 14d, the strong coherence in the time series is observed between the first modes of the $\left[\mathrm{O}_{3 \mathrm{LT}}\right]$ and $\left[\mathrm{NO}_{2 \mathrm{LT}}\right]$ with a correlation coefficient of 0.98 . The results of SVD analyses suggest that the long-term variations of $\mathrm{O}_{3}$ and $\mathrm{NO}_{2}$ in South Korea have similar temporal evolutions with different spatial patterns.

The differences in spatial patterns of $\left[\mathrm{O}_{3 \mathrm{LT}}\right]$ and $\left[\mathrm{NO}_{2} \mathrm{LT}\right]$ as shown in Fig. 14a and b require to be further investigated. Since the VOC emissions from industry, transportation, and the solvent usage in construction are large in South Korea (KMOE, 2013), further analyses of VOC measurements 
(a) $\left[\mathrm{O}_{3 \mathrm{BL}}\right]$ trend

(b) $\left[\mathrm{O}_{3 \text { SEASON }}\right]$ trend

(c) $\left[\mathrm{O}_{3 \mathrm{LT}}\right]$ trend

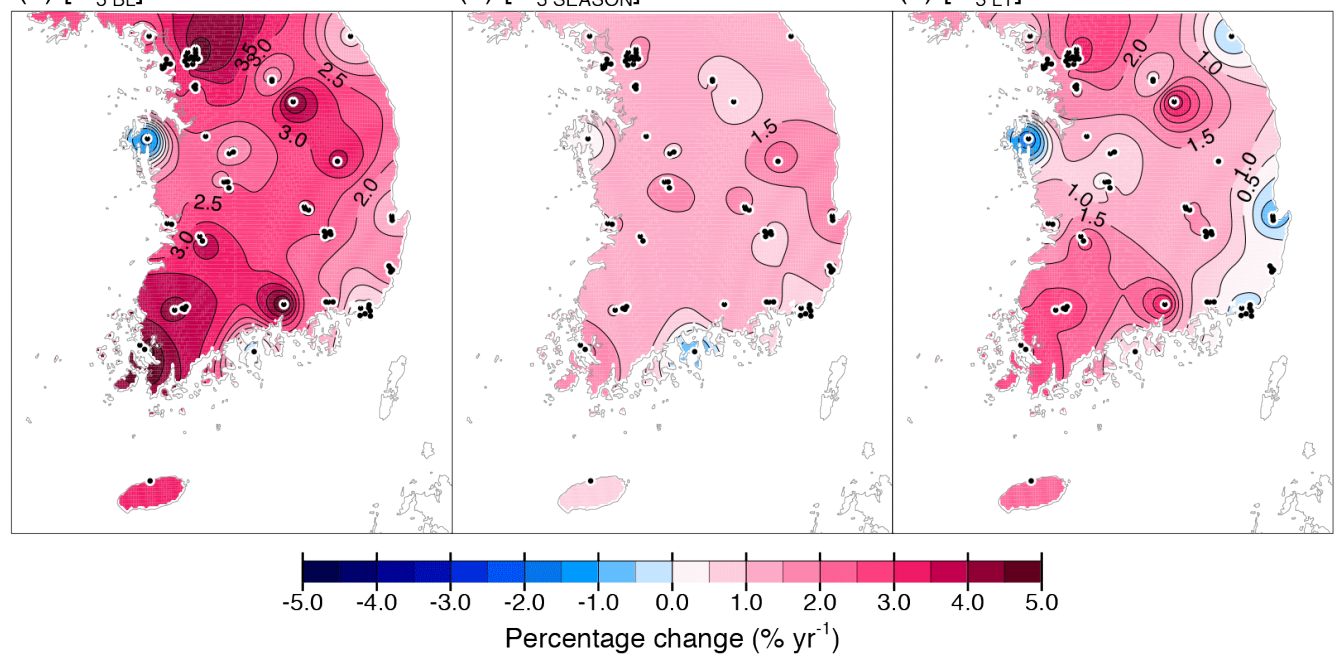

Figure 13. Spatial distributions of temporal linear trends of the (a) baseline $\left(\left[\mathrm{O}_{3 \mathrm{BL}}\right]\right)$, (b) seasonal component $\left(\left[\mathrm{O}_{3 \mathrm{SEASON}}\right]\right)$, and $(\mathbf{c})$ long-term component $\left(\left[\mathrm{O}_{3 \mathrm{LT}}\right]\right)$ for the period 2000-2009 using data from 72 air quality monitoring sites of NIER.

are needed. On top of that, especially in South Korea, biogenic precursor emissions are also potentially important for the analysis due to dense urban vegetation in and around metropolitan areas. Therefore, there remains the limitation of our current data analysis due to the lack of both VOC emission data and observations of atmospheric concentrations of VOCs in South Korea.

\section{Conclusions}

This study has investigated various spatiotemporal features and the interrelationship of surface $\mathrm{O}_{3}$ and related meteorological variables over South Korea based on ground measurements for the period 1999-2010. A general overview of surface $\mathrm{O}_{3}$ in terms of spatial distributions and its temporal trend is provided based on its decomposed components by the KZ filter.

In South Korea, the $\mathrm{O}_{3}$ concentrations are low at the inland and SMA cities due to the $\mathrm{NO}_{\mathrm{x}}$ titration by anthropogenic emissions and high at the coastal cities possibly due to the dynamic effects of the sea breeze. The averaged $\mathrm{O}_{3}$ levels in South Korea have increased for the period 1999-2010 with an averaged temporal linear trend of $+0.26 \mathrm{ppbv} \mathrm{yr}^{-1}$ $\left(+1.15 \% \mathrm{yr}^{-1}\right)$. The recent increase of the $\mathrm{O}_{3}$ levels in East Asia may result from the recent increase of anthropogenic precursor emissions and the long-term variations in meteorological effects.

We applied a linear regression model to investigate the relationships between $\mathrm{O}_{3}$ and meteorological variables such as temperature, insolation, dew-point temperature, sea-level pressure, wind speed, and relative humidity. Spatial distribution of the $R^{2}$ values shows high meteorological influences in the SMA and inland regions and low meteorological in- fluences in the coastal region. The high meteorological influences in the SMA and inland regions are related to effective photochemical activity, which results from large local precursor emissions and stagnant conditions with low wind speeds. However, the low meteorological influences in the coastal region are related to large transport effects of the background $\mathrm{O}_{3}$ and ventilation and dry deposition with high wind speeds.

In the SMA and inland region, the high $\mathrm{O}_{3}$ probability $\left(\mathrm{O}_{38 \mathrm{~h}}>60 \mathrm{ppbv}\right)$ increases with the daily maximum temperature rise. Specifically in the SMA, the most populated area in South Korea, the probability of the $\mathrm{O}_{3}$ exceedances is almost doubled by a $4{ }^{\circ} \mathrm{C}$ increase in daily maximum temperature and reached $27 \%$ at $30^{\circ} \mathrm{C}$. It is noted that the variations in $\mathrm{O}_{3}$ exceedance probabilities according to the maximum temperature show an approximate logarithmic increase in the SMA and inland regions. It thus implies that these regions will experience more frequent high $\mathrm{O}_{3}$ events in future climate conditions with the increasing global temperature.

The $\mathrm{O}_{3}$ time series observed at each monitoring site can be decomposed into the short-term, seasonal, and long-term components by the KZ filter. Relative contributions of each separated component show that the short-term and seasonal variations account for most of the $\mathrm{O}_{3}$ variability. Relative contributions of the short-term component are large at the coastal cities due to influence of the background $\mathrm{O}_{3}$ transport. In contrast, those of the seasonal component are large at the inland cities due to the high meteorological influences on the $\mathrm{O}_{3}$ variations.

The transport effects on the short-term component are shown in the probability distributions of both high shortterm component values and $\mathrm{O}_{3}$ exceedances for each wind direction. During the months of frequent high $\mathrm{O}_{3}$ events (May-October) in South Korea, the probabilities of both high 
(a) $\left[\mathrm{O}_{3 L T}\right]$ mode 1

(b) $\left[\mathrm{NO}_{2 L T}\right]$ mode 1

(c) $\left[\mathrm{NO}_{2 L \mathrm{~T}}\right]$ trend

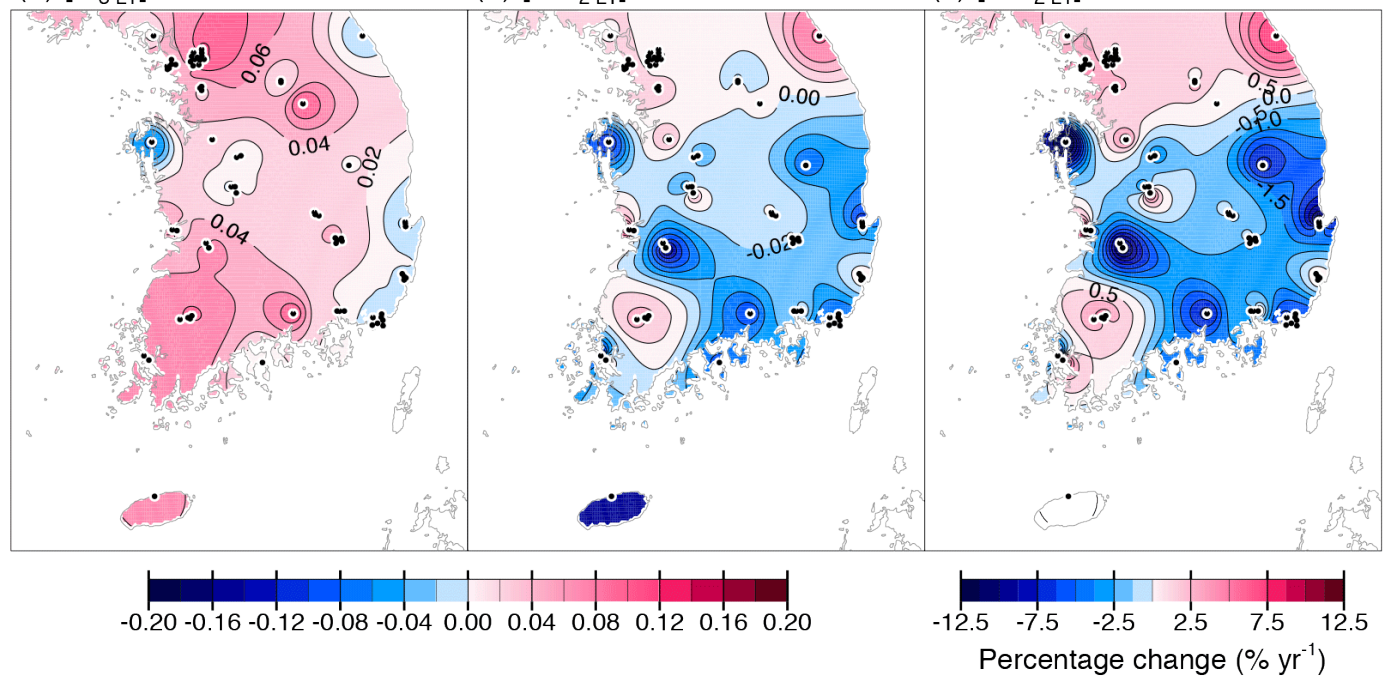

(d) Time series mode 1 (SCF: $63.7 \%, \mathrm{R}=0.98$ )

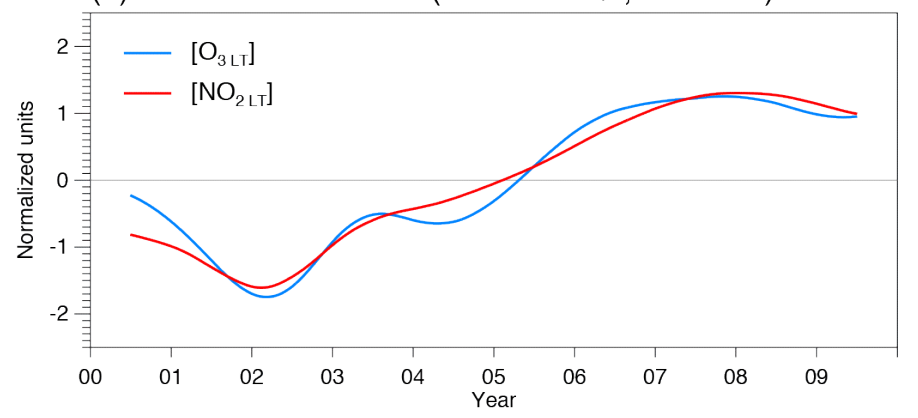

Figure 14. The first leading mode of SVD between the long-term components of (a) daily maximum $8 \mathrm{~h}$ average $\mathrm{O}_{3}\left(\left[\mathrm{O}_{3} \mathrm{LT}\right]\right)$ and (b) daily average $\mathrm{NO}_{2}\left[\mathrm{NO}_{2 \mathrm{LT}}\right]$ for the period 2000-2009. (c) Spatial distribution of temporal linear trends of [NO $\left.2 \mathrm{LT}\right]$. (d) Time series of the SVD expansion coefficient associated with $\left[\mathrm{O}_{3 \mathrm{LT}}\right]$ mode (blue line) and $\left[\mathrm{NO}_{2} \mathrm{LT}\right]$ mode (red line).

short-term component $\mathrm{O}_{3}$ and $\mathrm{O}_{3}$ exceedances are higher in the near-westerly wind condition rather than in other wind directions. For the short-term timescale, the eastward longrange transport of $\mathrm{O}_{3}$ and precursors from China can cause the nationwide high probabilities of $\mathrm{O}_{3}$ exceedances in the near-westerly wind condition. However, the high probabilities of extreme $\mathrm{O}_{3}$ events in downwind regions of the thermoelectric power plants and industrial complexes are related to local transport of $\mathrm{O}_{3}$ precursors, which apparently enhances the $\mathrm{O}_{3}$ levels.

The distribution of $\mathrm{O}_{3}$ trends in South Korea is spatially inhomogeneous. Although the relative contributions of the long-term components are much smaller than those of the other two components. Such a spatially inhomogeneous distribution of the $\mathrm{O}_{3}$ trend is mainly caused by the long-term component $\mathrm{O}_{3}$ trends rather than the seasonal component $\mathrm{O}_{3}$ trend related to the long-term change of meteorological conditions, which is because the long-term change of the local precursor emission has a localized effect on the long-term $\mathrm{O}_{3}$ change. The $\mathrm{SVD}$ between $\mathrm{O}_{3}$ and $\mathrm{NO}_{2}$ shows that the longterm variations of $\mathrm{O}_{3}$ and $\mathrm{NO}_{2}$ in South Korea have similar temporal evolutions with different spatial patterns. The results of SVD analyses clearly demonstrate the influences of local precursor emissions on the long-term changes in $\mathrm{O}_{3}$. However, the precise interpretation of the large spatially inhomogeneous distribution in the long-term component $\mathrm{O}_{3}$ trend is limited due to the lack of VOC measurements data.

The KZ filter is a useful diagnostic tool to reveal the spatiotemporal features of $\mathrm{O}_{3}$ and its relationship with meteorological variables. General features revealed by the KZ filter analysis will provide a better understanding of spatial and temporal variations of surface $\mathrm{O}_{3}$ as well as possible influences of local emissions, transport, and climate change on $\mathrm{O}_{3}$ levels in South Korea. Our analyses can also be helpful as a reference for the evaluation of chemistry transport models and furthermore for establishing appropriate $\mathrm{O}_{3}$ control policies.

The Supplement related to this article is available online at doi:10.5194/acp-14-6395-2014-supplement. 
Acknowledgements. This study has been funded by the Green City Technology Flagship Program of the Korea Institute of Science and Technology. D. Youn was supported by Chungbuk National University. This work was done as H. Lee's private venture and not in the author's capacity as an employee of the Jet Propulsion Laboratory, California Institute of Technology. The authors also appreciate constructive comments from two anonymous referees.

Edited by: K. Schaefer

\section{References}

Akimoto, H.: Global air quality and pollution, Science, 302, 17161719, doi:10.1126/science.1092666, 2003.

Bell, M. L., Goldberg, R., Hogrefe, C., Kinney, P. L., Knowlton, K., Lynn, B., Rosenthal, J., Rosenzweig, C., and Patz., J. A.: Climate change, ambient ozone, and health in 50 US cities, Clim. Change, 82, 61-76, doi:10.1007/s10584-006-9166-7, 2007.

Bernard, S. M., Samet, J. M., Grambsch, A., Ebi, K. L., and Romieu, I.: The potential impacts of climate variability and change on air pollution-related health effects in the United States, Environ. Health Persp., 109, 199-209, 2001.

Boo, K.-O., Kwon, W.-T., and Baek, H.-J.: Change of extreme events of temperature and precipitation over Korea using regional projection of future climate change, Geophys. Res. Lett., 33, L01701, doi:10.1029/2005GL023378, 2006.

Camalier, L., Cox, W., and Dolwick, P.: The effects of meteorology on ozone in urban areas and their use in assessing ozone trends, Atmos. Environ., 41, 7127-7137, doi:10.1016/j.atmosenv.2007.04.061, 2007.

Carmichael, G. R., Uno, I., Phadnis, M. J., Zhang, Y., and Sunwoo, Y.: Tropospheric ozone production and transport in the springtime in East Asia, J. Geophys. Res., 103, 10649-10671, doi:10.1029/97JD03740, 1998.

Chatani, S. and Sudo, K.: Influences of the variation in inflow to East Asia on surface ozone over Japan during 1996-2005, Atmos. Chem. Phys., 11, 8745-8758, doi:10.5194/acp-11-87452011, 2011.

Dawson, J. P., Adams, P. J., and Pandis, S. N.: Sensitivity of ozone to summertime climate in the eastern USA: A modeling case study, Atmos. Environ., 41, 1494-1511, doi:10.1016/j.atmosenv.2006.10.033, 2007.

Dibb, J. E., Talbot, R. W., Scheuer, E., Seid, G., DeBell, L., Lefer, B., and Ridley, B.: Stratospheric influence on the northern North American free troposphere during TOPSE: ${ }^{7} \mathrm{Be}$ as a stratospheric tracer, J. Geophys. Res., 108, 8363, doi:10.1029/2001JD001347, 2003.

Diem, J. E.: A critical examination of ozone mapping from a spatial-scale perspective, Environ. Pollut., 125, 369-383, doi:10.1016/S0269-7491(03)00110-6, 2003.

Ding, A. J., Wang, T., Thouret, V., Cammas, J.-P., and Nédélec, P.: Tropospheric ozone climatology over Beijing: analysis of aircraft data from the MOZAIC program, Atmos. Chem. Phys., 8, 1-13, doi:10.5194/acp-8-1-2008, 2008.

Eskridge, R. E., Ku, J. Y., Rao, S. T., Porter, P. S., and Zurbenko, I. G.: Separating different scales of motion in time scales of motion in time series of meteorological variables, B. Am. Meteorol. Soc., 78, 1473-1483, doi:10.1175/15200477(1997)078<1473:SDSOMI>2.0.CO;2, 1997.
Flaum, J. B., Rao, S. T., and Zurbenko, I. G.: Moderating the influence of meteorological conditions on ambient ozone concentrations, J. Air Waste Manage., 46, 35-46, doi:10.1080/10473289.1996.10467439, 1996.

Gardner, M. W. and Dorling, S. R.: Meteorologically adjusted trends in UK daily maximum surface ozone concentrations, Atmos. Environ., 34, 171-176, doi:10.1016/S13522310(99)00315-5, 2000.

Ghim, Y. S.: Trends and factors of ozone concentration variations in Korea, Journal of Korean Society for Atmospheric Environment, 16, 607-623, 2000 (in Korean).

Ghim, Y. S. and Chang, Y. S.: Characteristics of ground-level ozone distribution in Korea for the period of 1990-1995, J. Geophys. Res., 105, 8877-8890, doi:10.1029/1999JD901179, 2000.

Ghim, Y. S., Oh, H. S., and Chang, Y. S.: Meteorological effects on the evolution of high ozone episodes in the Greater Seoul Area, J. Air Waste Manage., 51, 185-202, doi:10.1080/10473289.2001.10464269, 2001.

Guicherit, R. and Roemer, M.: Tropospheric ozone trends, Chemosphere-Global Change Science, 2, 167-183, 2000.

Ibarra-Berastegi, G., Madariaga, I., Elías, A., Agirre, E., and Uria, J.: Long-term changes of ozone and traffic in Bilbao, Atmos. Environ., 35, 5581-5592, doi:10.1016/S1352-2310(01)00210-2, 2001.

IPCC (Intergovernmental Panel on Climate Change): Climate Change 2007: The Physical Scientific Basis: Contribution of Working Group I to the Fourth Assessment Report of the Intergovernmental Panel on Climate Change, edited by: Solomon, S., Qin, D., Manning, M., Chen, Z., Marquis, M., Averyt, K. B., Tignor, M., and Miller, H. L., Cambridge University Press, Cambridge, United Kingdom and New York, NY, USA, 2007.

Jacob, D. J. and Winner, D. A.: Effect of climate change on air quality, Atmos. Environ., 43, 51-63, doi:10.1016/j.atmosenv.2008.09.051, 2009.

Jacob, D. J., Logan, J. A., and Murti, P. P.: Effect of rising Asian emissions on surface ozone in the United States, Geophys. Res. Lett., 26, 2175-2178, doi:10.1029/1999GL900450, 1999.

Jaffe, D. A., Parrish, D., Goldstein, A., Price, H., and Harris, J.: Increasing background ozone during spring on the west coast of North America, J. Geophys. Res., 30, 1613, doi:10.1029/2003GL017024, 2003.

Jin, L., Lee, S.-H., Shin, H.-J., and Kim, Y. P.: A study on the ozone control strategy using the OZIPR in the Seoul Metropolitan Area, Asian J. Atmos. Environ., 6, 111-117, doi:10.5572/ajae.2012.6.2.111, 2012.

Kim, J. Y., Kim, S.-W., Ghim, Y. S., Song, C. H., and Yoon, S.-C.: Aerosol properties at Gosan in Korea during two pollution episodes caused by contrasting weather conditions, AsiaPacific, J. Atmos. Sci., 48, 25-33, doi:10.1007/s13143-0120003-9, 2012.

KMOE (Ministry of Environment, Korea): Annual report of ambient air quality in Korea, 2011, 11-1480523-000198-10, National Institute of Environmental Research, Environmental Research Complex, Incheon, available at: http://webbook.me.go. kr/DLi-File/091/012/5515496.PDF (last access: 18 June 2014), 2012 (in Korean).

KMOE (Ministry of Environment, Korea): Air pollutants emission (1999-2010), 11-1480523-001377-01, National Institute of Environmental Research, Environmental Research Complex, In- 
cheon, available at: http://webbook.me.go.kr/DLi-File/NIER/09/ 018/5553596.pdf, (last access: 18 June 2014), 2013 (in Korean).

Lei, H., Wuebbles, D. J., Liang, X.-Z., and Olsen, S.: Domestic versus international contributions on 2050 ozone air quality: How much is convertible by regional control?, Atmos. Environ., 68, 315-325, doi:10.1016/j.atmosenv.2012.12.002, 2013.

Lei, H. and Wang, J. X. L.: Sensitivities of $\mathrm{NO}_{\mathrm{x}}$ transformation and the effects on surface ozone and nitrate, Atmos. Chem. Phys., 14, 1385-1396, doi:10.5194/acp-14-1385-2014, 2014.

Levy, H., Mahlman, J., Moxim, W. J., and Liu, S.: Tropospheric ozone: the role of transport, J. Geophys. Res., 90, 3753-3772, doi:10.1029/JD090iD02p03753, 1985.

Levy, J. I., Chemerynski, S. M., and Sarnat, J. A.: Ozone exposure and mortality: an empiric Bayes metaregression analysis, Epidemiology, 16, 458-468, doi:10.1097/01.ede.0000165820.08301.b3, 2005.

Lin, C. Y. C., Jacob, D. J., and Fiore, A. M.: Trends in exceedances of the ozone air quality standard in the continental United States, 1980-1998, Atmos. Environ., 35, 3217-3228, doi:10.1016/S1352-2310(01)00152-2, 2001.

Lin, J.-T., Patten, K. O., Hayhoe, K., Liang, X.-Z., and Wuebbles, D. J.: Effects of future climate and biogenic emissions changes on surface ozone over the United States and China, J. Appl. Meteorol. Clim., 47, 1888-1909, doi:10.1175/2007JAMC1681.1, 2008.

Liu, S. C., Trainer, M., Fehsenfeld, F. C., Parrish, D. D., Williams, E. J., Fahey, D. W., Hübler, G., and Murphy, P. C.: Ozone production in the rural troposphere and the implications for regional and global ozone distributions, J. Geophys. Res., 92, D4, 4191-4207, doi:10.1029/JD092iD04p04191, 1987.

Logan, J. A.: Tropospheric ozone: seasonal behavior, trends and anthropogenic influence, J. Geophys. Res., 90, 463-482, doi:10.1029/JD090iD06p10463, 1985.

Lu, H. C. and Chang, T. S.: Meteorologically adjusted trends of daily maximum ozone concentrations in Taipei, Taiwan, Atmos. Environ., 39, 6491-6501, doi:10.1016/j.atmosenv.2005.06.007, 2005.

Lu, G. Y. and Wong, D. W.: An adaptive inverse-distance weighting spatial interpolation technique, Comput. Geosci., 34, 1044-1055, doi:10.1016/j.cageo.2007.07.010, 2008.

Mickley, L. J., Jacob, D. J., and Field, B. D.: Climate response to the increase in tropospheric ozone since preindustrial times: A comparison between ozone and equivalent $\mathrm{CO}_{2}$ forcings, J. Geophys. Res., 109, D05106, doi:10.1029/2003JD003653, 2004.

Milanchus, M. L., Rao, S. T., and Zurbenko, I. G.: Evaluating the effectiveness of ozone management efforts in the presence of meteorological variability, J. Air Waste Manage., 48, 201-215, doi:10.1080/10473289.1998.10463673, 1998.

Nagashima, T., Ohara, T., Sudo, K., and Akimoto, H.: The relative importance of various source regions on East Asian surface ozone, Atmos. Chem. Phys., 10, 11305-11322, doi:10.5194/acp10-11305-2010, 2010.

Oh, I. B., Kim, Y. K., Lee, H. W., and Kim, C. H.: An observational and numerical study of the effects of the late sea breeze on ozone distributions in the Busan metropolitan area, Korea, Atmos. Environ., 40, 1284-1298, doi:10.1016/j.atmosenv.2005.10.049, 2006.

Oh, I. B., Kim, Y. K., Hwang, M. K., Kim, C. H., Kim, S., and Song, S. K.: Elevated ozone layers over the Seoul Metropolitan Region in Korea: Evidence for long-range ozone transport from eastern
China and its contribution to surface concentrations, J. Appl. Meteorol. Clim., 49, 203-220, doi:10.1175/2009JAMC2213.1, 2010.

Olszyna, K. J., Luria, M., and Meagher, J. F.: The correlation of temperature and rural ozone levels in southeastern U.S.A., Atmos. Environ., 31, 3011-3022, doi:10.1016/S13522310(97)00097-6, 1997.

Oltmans, S. J., Lefohn, A. S., Scheel, H. E., Harris, J. M., Levy II, H., Galbally, I. E., Brunke, E.-G., Meyer, C. P., Lathrop, J. A., Johnson, B. J., Shadwick, D. S., Cuevas, E., Schmidlin, F. J., Tarasick, D. W., Claude, H., Kerr, J. B., Uchino, O., and Mohnen, V.: Trends of ozone in the troposphere, Geophys. Res. Lett., 25, 139-142, doi:10.1029/97GL03505, 1998.

Oltmans, S. J., Lefohn, A. S., Harris, J. M., Galbally, I., Scheel, H. E., Bodeker, G., Brunke, E., Claude, H., Tarasick, D., Johnson, B. J., Simmonds, P., Shadwick, D., Anlauf, K., Hayden, K., Schmidlin, F., Fujimoto, T., Akagi, K., Meyer, C., Nichol, S., Davies, J., Redondas, A., and Cuevas, E.: Long-term changes in tropospheric ozone, Atmos. Environ., 40, 3156-3173, doi:10.1016/j.atmosenv.2006.01.029, 2006.

Oltmans, S. J., Lefohn, A. S., Shadwick, D., Harris, J. M., Scheel, H. E., Galbally, I., Tarasick, D. W., Johnson, B. J., Brunke, E.G., Claude, H., Zeng, G., Nichol, S., Schmidlin, F., Davies, J., Cuevas, E., Redondas, A., Naoe, H., Nakano, T., and Kawasato, T.: Recent tropospheric ozone changes - A pattern dominated by slow or no growth, Atmos. Environ., 67, 331-351, doi:10.1016/j.atmosenv.2012.10.057, 2013.

Ordóñez, C., Mathis, H., Furger, M., Henne, S., Hüglin, C., Staehelin, J., and Prévôt, A. S. H.: Changes of daily surface ozone maxima in Switzerland in all seasons from 1992 to 2002 and discussion of summer 2003, Atmos. Chem. Phys., 5, 1187-1203, doi:10.5194/acp-5-1187-2005, 2005.

Racherla, P. N. and Adams, P. J.: Sensitivity of global tropospheric ozone and fine particulate matter concentrations to climate change, J. Geophys. Res., 111, D24103, doi:10.1029/2005JD006939, 2006.

Rao, S. T. and Zurbenko, I. G.: Detecting and tracking changes in ozone air quality, J. Air Waste Manage., 44, 1089-1092, doi:10.1080/10473289.1994.10467303, 1994.

Rao, S. T., Zalewsky, E., and Zurbenko, I. G.: Determining temporal and spatial variations in ozone air quality, J. Air Waste Manage., 45, 57-61, doi:10.1080/10473289.1995.10467342, 1995.

Rao, S. T., Zurbenko, I. G., Neagu, R., Porter, P. S., Ku, J. Y., and Henry, R. F.: Space and time scales in ambient ozone data, B. Am. Meteorol. Soc., 78, 2153-2166, doi:10.1175/15200477(1997)078<2153:SATSIA>2.0.CO;2, 1997.

Rasmussen, D. J., Fiore, A. M., Naik, V., Horowitz, L. W., McGinnis, S. J., and Schultz, M. G.: Surface ozone-temperature relationships in the eastern US: A monthly climatology for evaluating chemistry-climate models, Atmos. Environ., 47, 142-153, doi:10.1016/j.atmosenv.2011.11.021, 2012.

Shin, H. J., Cho, K. M., Han, J. S., Kim, J. S., and Kim, Y. P.: The effects of precursor emission and background concentration changes on the surface ozone concentration over Korea, Aerosol Air Qual. Res., 12, 93-103, doi:10.4209/aaqr.2011.09.0141, 2012.

Sillman, S. and Samson, P. J.: Impact of temperature on oxidant photochemistry in urban, polluted rural and re- 
mote environments, J. Geophys. Res., 100, 11497-11508, doi:10.1029/94JD02146, 1995.

Tang, G., Wang, Y., Xin, J., and Ren, X.: Surface ozone trend details and interpretations in Beijing, 2001-2006, Atmos. Chem. Phys., 9, 8813-8823, doi:10.5194/acp-9-8813-2009, 2009.

Tanimoto, H., Sawa, Y., Matsueda, H., Uno, I., Ohara, T., Yamaji, K., Kurokawa, J., and Yonemura, S.: Significant latitudinal gradient in the surface ozone spring maximum over East Asia, Geophys. Res. Lett., 32, L21805, doi:10.1029/2005GL023514, 2005.

Tanimoto, H., Ohara, T., and Uno, I.: Asian anthropogenic emissions and decadal trends in springtime tropospheric ozone over Japan: 1998-2007, Geophys. Res. Lett., 36, L23802, doi:10.1029/2009GL041382, 2009.

Thompson, M. L., Reynolds, J. R., Cox, L. H., Guttorp, P., and Sampson, P. D.: A review of statistical methods for the meteorological adjustment of tropospheric ozone, Atmos. Environ., 35, 617-630, doi:10.1016/S1352-2310(00)00261-2, 2001.

Tilmes, S. and Zimmermann, J.: Investigation on the spatial scales of the variability in measured near-ground ozone mixing ratios, Geophys. Res. Lett., 25, 3827-3830, doi:10.1029/1998GL900034, 1998.

Tsakiri, K. G. and Zurbenko, I. G.: Prediction of ozone concentrations using atmospheric variables, Air Quality, Atmosphere \& Health, 4, 111-120, doi:10.1007/s11869-010-0084-5, 2011.

Vingarzan, R.: A review of surface ozone background levels and trends, Atmos. Environ., 38, 3431-3442, doi:10.1016/j.atmosenv.2004.03.030, 2004.
Wang, T., Wei, X. L., Ding, A. J., Poon, C. N., Lam, K. S., Li, Y. S., Chan, L. Y., and Anson, M.: Increasing surface ozone concentrations in the background atmosphere of Southern China, 19942007, Atmos. Chem. Phys., 9, 6217-6227, doi:10.5194/acp-96217-2009, 2009.

Wang, X. and Mauzerall, D. L.: Characterizing distributions of surface ozone and its impact on grain production in China, Japan and South Korea: 1990 and 2020, Atmos. Environ., 38, 43834402, doi:10.1016/j.atmosenv.2004.03.067, 2004.

Wang, Y., Konopka, P., Liu, Y., Chen, H., Müller, R., Plöger, F, Riese, M., Cai, Z., and Lü, D.: Tropospheric ozone trend over Beijing from 2002-2010: ozonesonde measurements and modeling analysis, Atmos. Chem. Phys., 12, 8389-8399, doi:10.5194/acp-12-8389-2012, 2012.

Wise, E. K. and Comrie, A. C.: Extending the KolmogorovZurbenko filter: Application to ozone, particulate matter, and meteorological trends, J. Air Waste Manage., 55, 1208-1216, doi:10.1080/10473289.2005.10464718, 2005.

Zhao, B., Wang, S. X., Liu, H., Xu, J. Y., Fu, K., Klimont, Z., Hao, J. M., He, K. B., Cofala, J., and Amann, M.: $\mathrm{NO}_{\mathrm{x}}$ emissions in China: historical trends and future perspectives, Atmos. Chem. Phys., 13, 9869-9897, doi:10.5194/acp-13-9869-2013, 2013. 